\title{
Killing and Skinning Animals in the Ur III Period: The Puzriš-Dagan (Drehem) Office Managing of Dead Animals and Slaughter By-products
}

\begin{abstract}
In an approach combining the analysis of key words with the prosopographical study of the relevant text sources, this article discusses the administration and processing of slaughter animals and their by-products in Ur III Puzriš-Dagan (Drehem). The study demonstrates that slaughter animals were administrated in a specialised government office with two subdivisions. One of these was responsible for the processing of the carcasses in the kitchens (Großküchen) of Puzriš-Dagan and elsewhere, the other for the utilisation of the skins and other by-products. The article includes discussions of the terms used for slaughter animals and their by-products as well as for the associated locations and officials.
\end{abstract}

Keywords: Ur III, Drehem (Puzriš-Dagan), administration, livestock agency, dead animals, slaughter byproducts, kitchen

\section{Introduction}

Puzriš-Dagan flourished as an administrative centre responsible for the management of livestock from all over the Ur III state. ${ }^{1}$ Almost 77,000 animals a year passed administratively through Puzriš-Dagan. Even so, neither in the literature nor in the primary sources is the final disposal of these thousands of animals managed by the central agency at Puzriš-

${ }^{1}$ Part of the research for this article was presented at the workshop 'Artisans and Professions in the Ur III Period' of the RAI in Rome, 2011. I would like to thank the organizer S. Garfinkle and other colleagues who provided useful comments and objections during the presentation of that paper. I would also like to thank B. Lafont, P. Michalowski, P. Paoletti and N. Postgate, who read previous drafts and provided very useful comments. Thanks are due to K. Sauer for her help with editing the text and tables, and especially to M. Richardson for polishing the English of the manuscript. Dates are given in the following format: abbreviated king's name ( $\breve{S}$ = Šulgi; AS = Amar-Suena; $\breve{S}$ = Šu-Suen; IS = Ibbi-Suen), followed by year (e.g. AS.01) or year, month and date (e.g. AS.01.05.23). The abbreviations U-H and I-Š used after the PN Lu-diĝira stand for Lu-diĝira son of Urdu-Hula and Lu-diĝira son of Inim-Šara, respectively. Otherwise, abbreviations follow those of the Cuneiform Digital Library Initiative (CDLI). For a reconstruction of Puzriš-Dagan offices and bureaus as employed here, see Tsouparopoulou (2013). 
Dagan explicitly mentioned. ${ }^{2}$ However, there was a specific office that received the carcasses of animals that had died or had been slaughtered, and from where they were presumably transferred to the kitchen and other destinations. This will be called the 'office for dead animals'. This office documented no transfers or disbursals. What information we have is based, for the dead animals, partly on the receipts of two main officials working in this office, Ur-niĝar and Sulgi-irighu, and partly on the receipts of carcasses and other slaughter by-products.

We still do not have a clear understanding of the final disposal of dead animals and slaughter by-products, but in one text (SET 87) the names of the final recipients in ŠS.09 are mentioned.

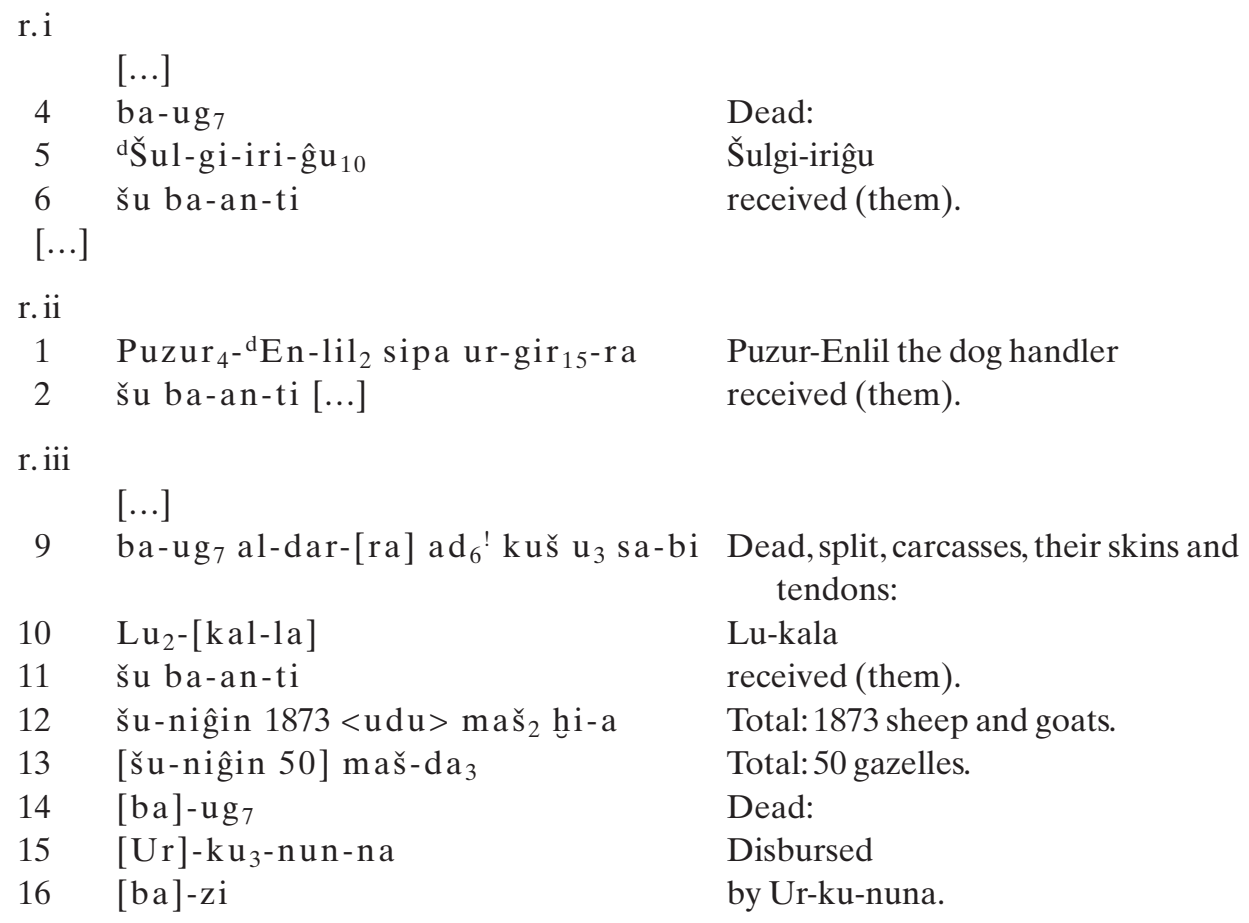

According to this text, the three people receiving dead animals and carcasses, Šulgi-iriĝu, the dog handler Puzur-Enlila and Lu-kala, received almost 2000 animals over a year from Ur-ku-nuna. ${ }^{3}$ From this text (and others; see below) one can say that (a) dead animals and by-products were transferred to a department that was responsible for the dead animals, headed possibly by Beli-arik and later by Ur-niĝar and Šulgi-iriĝu, which may have been related to the kitchen and (b) given to dog handlers, sometimes as part of regular deliveries

${ }^{2}$ Based on tablets $A O 19548$ (RA 63:102) and $A O 19550$ (RA 63: 104), Sigrist (1992: 33-34) estimated that around 77,000 animals were transferred from and to Puzriš-Dagan each year. See also Sallaberger (2004:3 n.6).

${ }^{3}$ For Ur-ku-nuna, see Tsouparopoulou (forthcoming: Cat. No. 459), with references to secondary literature. 
for the kennels; and that (c) carcasses were given to a separate department that was specifically responsible for the management and storage of carcasses and hides. This department was probably originally headed by Naram-ili, and subsequently by Nur-Suen and Lu-kala.

Although an 'office for dead animals' is never mentioned as such in the secondary literature or in the primary sources, it was one of the most important units in the organization of Puzriš-Dagan. Some of its officials were connected with the kitchen and therefore concerned with feeding officials, foreign emissaries, etc. (Allred 2006). ${ }^{4}$ It seldom received animals from the office of the chief official; the shepherds' office usually sent the dead animals directly to the kitchen and only rarely through this office. The animals that this office received came mainly from the disbursal office and branch offices located outside Puzriš-Dagan, such as that at Tummal, the nakabtum organization, ${ }^{5}$ the royal court, and that at Ur/Nippur, etc. The officials of the office for dead animals never disbursed the dead animals they received.

This office had two departments. The main department dealt with dead animals for the kitchen and was headed by Beli-arik, Ur-nighar and Šulgi-iriĝu. The other was associated with leather (i.e. hides) and wool as raw materials and was headed by Nur-Suen and Lukala. The kitchen department had one supervisor at any given time. ${ }^{6}$ First it was Beli-arik until Š.44; he was followed by Ur-nighar from Š.44 until AS.03.05.04; but his successor Šulgiirighu shared the responsibility for a few months. He started receiving dead animals in AS.03.01 and took over full responsibility at least as early as AS.03.04.08 and remained in post until IS.02, when the Drehem archives cease. The separation into two departments is evident only from Amar-Suena's reign onwards, when Nur-Suen controlled hides.

It will be best to examine the terminology for dead animals and their by-products as well as the places and professions involved in their administration, mainly from texts stemming from the Drehem archive, before describing the different departments of the office for dead animals further.

${ }^{4}$ Note however that the officials heading this office, Beli-arik, Ur-nighar and Šulgi-iriĝu, are almost never explicitly associated with the kitchen $\left(e_{2}\right.$-muhaldim). This could perhaps be explained by a lack of pertinent tablets. What is available are a few tablets recording deliveries of animals received by

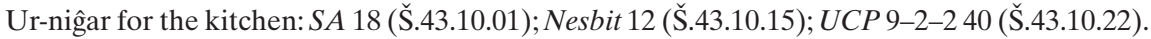

${ }^{5}$ For the nakabtum organization, see now Brunke (2008).

${ }^{6}$ Many tablets documenting receipts of dead animals by Šulgi-iriĝu and attributed to Š.42 should instead be dated to AS.06, since the Puzriš-Dagan scribes used the same year-name form for Š.42 as for AS.06. Three tablets have been published documenting the receipt by Šulgi-iriĝu of dead animals in Š.45, Š. 47 and AS.01. However, all three tablets have either been dated wrongly or the name of the official who received the animals has been reconstructed wrongly. Rochester 16, with Š.45 given as its date, should be dated to ŠS.04 like the other tablets in which an Ur-Nanna transfers several dead animals to Šulgiiriĝu (SA 31; TRU 250; JCS 35:204.7; etc.). The year name has been given as mu us $\mathrm{s}_{2}$-sa si-[mu-ru$\mathrm{um}^{\mathrm{ki}}$ ba-hul] whereas it should be mu us ${ }_{2}$-sa si-[ma-/ $\mathrm{num}_{2}{ }^{\mathrm{ki}}$ ba-hul]. AnOr 7:120, dated to Š.47, should also be dated to ŠS.04, according to its transliteration (mu us ${ }_{2}-[\mathrm{sa}] \mathrm{Si}-\mathrm{ma}-/ \mathrm{num}_{2}{ }^{\mathrm{ki}}$ bahul). In OIP 121: 433, dated to AS.01, the name of the receiving official has been reconstructed as Šulgi-iriĝ, whereas it should be Ur-nighar. 


\section{Dead Animals and Slaughter By-products Documented at Drehem}

There is a generic designation for animals being transferred between offices at PuzrišDagan to denote that they had been slaughtered ( $\mathrm{ba}-\mathrm{ug}_{7}$ ). Most of these dead animals were sent to the kitchen to feed soldiers, messengers and personnel stationed at PuzrišDagan and beyond. Several officials active within the Puzriš-Dagan administration sent them on, usually directly to Ur-nighar and Šulgi-iriĝu or to the kitchen ( $e_{2}$-muhaldim) via $\left(\hat{g} \mathrm{ri}_{3}\right)$ Ur-nighar and Šulgi-irighu. Of the more than 2500 references to ba-ug $\mathrm{g}_{7}$ animals in the Drehem archives there does not appear to have been any distinction between animals that had died accidentally or for other reasons (ri-ri-ga, 'fallen') and animals that had been slaughtered (Steinkeller 1995:55). ${ }^{7}$

There are more than 1500 instances of animals for human consumption, designated as šu-gid ${ }_{2}$, which according to Lafont means 'choisis pour la cuisine' (2009: 426). Similar conclusions were reached by Brunke (2011: 182), who discussed the fact that šu-gid $\mathrm{d}_{2}$ - as a qualitative designation - was usually found in association with the kitchen ( $\mathrm{e}_{2}$-muhaldim), and by Sigrist (1992: 40-42), Allred (2006) and Sallaberger (1993: 29). By contrast Englund (2004: 40) considers such an animal destined for divination, possibly because the verb šu-gid 2 is associated with extispicy (Karahashi 2000: 161-162). However, another term ( $\mathrm{kin}-\mathrm{gi}_{4}$-a) indicated lambs for divination (Steinkeller 1995; Heimpel 1993: 131-33), and although animals designated for divination were consumed afterwards, ${ }^{8}$ they would hardly constitute routine food for soldiers and one cannot easily account for the quantities attested with this interpretation.

This term, šu-gid 2 , occurs at Drehem only from $\breve{S} .42$ onwards and is not found in the

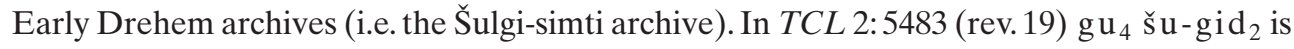
contrasted with $\mathrm{gu}_{4}$ gi ̌̌ , but the significance of this distinction is unclear. Sigrist (1992: 41) understands $\mathrm{gu}_{4}$ giš as oxen able to do agricultural work, in contrast to $\mathrm{gu}_{4} \breve{\mathrm{su}}$ - $\mathrm{gid}_{2}$. Another text, OrSP 47-49: 121, lists wild goats, sheep and ewes as gur u $\mathrm{m}_{2}$ - $\mathrm{a} \mathrm{m}_{3}$ ('inspected') as well as others described as šu-gid ${ }_{2}-\mathrm{am}_{3}$. It seems that any animal could be described as šu-gid ${ }_{2}$, including female and male equids ( $\mathrm{dusu}_{2}$, anše $\mathrm{si}_{2}$-si $\left.{ }_{2}\right)$, female kids, cows $\left(\mathrm{ab}_{2}\right)$, goats $\left(\mathrm{mas}_{2}, \mathrm{dara}_{4}, \mathrm{uzud}\right)$, sheep ( $\left.\mathrm{udu}\right)$, ewes $\left(\mathrm{u}_{8}\right)$, lambs $\left(\mathrm{sila}_{4}, \mathrm{kir}_{11}\right)$, oxen $\left(\mathrm{gu}_{4}\right)$, gazelles $\left(\mathrm{maš}-\mathrm{da}_{3}\right)$ and others. Moreover, even though most $\breve{\mathrm{u}}-\mathrm{gid}_{2}$ animals are associated with the kitchen, there are also transactions of such animals among different bureaus within the Puzriš-Dagan administration, such as between Abba-saga and Intaea, ${ }^{9} \mathrm{Nalu}$ and Nasa, ${ }^{10}$ and Nalu and Ur-ku-nuna. ${ }^{11}$ Several cattle herders $\left(\mathrm{unu}_{3}\right)$ and shepherds ( sipa) also gave šu-gid 2 animals to the Puzriš-Dagan central agency. ${ }^{12}$ Car-

7 The term ri-ri-ga is common in the Šulgi-simti archive (Sallaberger 1994:53) as well as in Girru and Umma. For the semantic difference between the expressions ba-uš $\check{L}_{2} / \mathrm{ug}_{7}$ and ri-ri-ga in the Umma texts, see Stępień (1996: 41 and n. 23;77-78;199).

${ }^{8}$ See BIN 3: 403, obv. 1-3, where military personnel ( $\mathrm{gara}_{3}-\mathrm{du}$ ) ate the meat of a sacrificial animal. For a discussion of this passage, see Hilgert 2003:22-23 and n. 76.

9 AAICAB 1/3, Bod.A 80 (AS.06.12.27): transfer of 703 šu-gid 2 animals from Abba-saga to Intaea.

${ }^{10}$ E.g. CST 76 (Š.44.07.30); CST 77 (Š.44.08.29); SumTemDocs. 12 (Š.46.03.30); Rocznik MNW 25 A

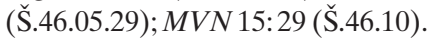

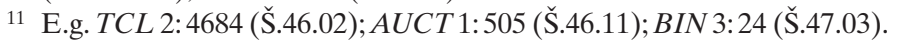

12 AUCT 2:235; MVN 8: 6; OIP 115:364, rev.22: šu-gid 2 ki unu ${ }_{3}-[\mathrm{e}]-\mathrm{ne}$; Nisaba 8:122; AUCT 2:303. 
casses, however, are never designated as šu-gid ${ }_{2}$, and yet most šu-gid 2 animals are sent to the kitchen. Taking these facts together suggests that the šu-gid 2 animals were considered slaughtered for food particularly suitable for being (Sigrist 1992). Most of them were sent from various Puzriš-Dagan officials to the kitchen, either directly or via ( $\hat{\mathrm{g}} \mathrm{ir}_{3}$ ) Ur-niĝar and Šulgi-iriĝu.

At least 61 Drehem texts dating from $\breve{S} .31$ to ŠS.09 concern animal carcasses (a d da).$^{13}$ Some are annual accounts, one for more than 4000 carcasses of ovines (Princeton 1: 118), and one concerns the carcasses and hides of 484 bovines collected at the storehouse ( $M V N$ 8: 146). The value of a carcass was relatively high, estimated by Englund (2003) to have been 1/5 to $1 / 10$ of that of a live animal. Many of the carcasses processed at Puzriš-Dagan were given as food to dogs or the female staff (usually weavers) ${ }^{14}$ while others were sent to the 'storeroom' ( $\left.e_{2}-k i s ̌ i b-b a\right)$.

The hides ( $\mathrm{kuš}$ ) were also usually sent to the storeroom, but occasionally they were given to Puzur-ili, the head of the leather industry at Puzriš-Dagan. ${ }^{15}$ From the few references to skinning in the Ur III documents, ${ }^{16}$ it seems that it may have been done at royal workshops, ${ }^{17}$ which would explain why skins and hides were brought into the palace (see below). Several animal herders seem to have sent carcasses together with their hides to Puzriš-Dagan, and the administrators could therefore track any losses from the state flocks. ${ }^{18}$ This corresponds to the obligation of the Old Babylonian shepherd to send back to the owner the skin and possibly tendons of all the animals that had died under his care; he was then given a receipt to prove his losses to the administration at shearing time (Postgate 1975:6).

Tendons ( s a) are also documented at Drehem, usually together with carcasses and hides. ${ }^{19}$ They could be fed to dogs (probably boiled) or used for making shoes. Tendons were usually measured by weight; one slaughtered sheep might yield 16 grams of tendons. ${ }^{20}$ Other by-products, such as hooves (umbin), tails (kun) (SACT 1:120) and horns (si) are sometimes mentioned, but without further details. ${ }^{21}$

${ }^{13}$ For a palaeographic discussion of $\mathrm{ad}_{6}, \mathrm{ad}_{7}$ and $\mathrm{ad}_{3}$ in the Ur III documentation, see Veldhuis (2008).

${ }^{14}$ CST 50; CST 45; OIP 115: 66, from the Šulgi-simti archive; BIN 3:2 (possibly also from the Šulgi-simti archive); OIP 115:325 obv. 1-4: $20 \mathrm{gu}_{4} 11 \mathrm{ab}_{2}$ ba-ug $_{7} \mathrm{ad}_{6}$-bi 12-am - geme $_{2}$ uš-bar e e $_{2}$ Amard ̌̌ul-gi-/ra-ke ${ }_{4}$ ba-ab-gu ${ }_{7}$, dated to Š.47.01.

15 See $A U C T$ 1: 950 (AS.03.05) and SAT 2: 838 for the transfer of tendons of sheep to be eaten by dogs. See now Paoletti (2012:183-199).

${ }^{16}$ E.g., Girsu texts: TUT 39 (SVS I/1:39) rev. 6: kuš gid ${ }_{2}$-da; TUT 82 (SVS I/1: 82) rev. 37: [kuš] gid $_{2}$ -

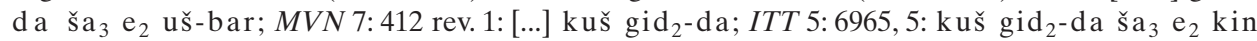
gur-ra; Drehem texts: TRU 14 obv. 2: [3+] sila ${ }_{4}$ ? ba-[ug $\left.{ }_{7}\right]$ ad 6 kuš-bi e ${ }_{2}$-gal-še ${ }_{3}$ gid $_{2}$-dam; UDT111 obv.1-2: $1 \mathrm{ab}_{2}$ ba-ug ad $_{6}$ ?-bi e 2 -gal-šs 3 ba-gid 2 .

17 See $U D T 111$ and $T R U 14$ in the preceding note.

${ }^{18}$ E.g. $B P O A$ 7:2240:60+10 ad ${ }_{6}$ udu, 2 ad $_{6}$ sila $_{4}$ giriri 3 sipa-e-ne ki Du ${ }_{11}$-ga-ta Ur-ku $u_{3}$-nun-na šu ba-ti, and YOS 4:253, which documents the transfer of 6523 carcasses of several types of animals from shepherds and cowherds of the fattening house $\left(\mathrm{e}_{2}\right.$-kuruš da), taken in charge by Šulgi-iriĝu.

19 PDT 1:515 rev.ii 22: ad 6 kuš u ${ }_{3}$ sa-bi; OIP 121:54:60 kuš udu sa-bi 2 ma-na.

${ }^{20} J C S$ 23:114,33:20: kuš udu sa-bi 2/3 ma-na; OIP 121:54 in preceding note.

${ }^{21}$ For slaughter by-products, see Englund (2003: §18-\$21). For umbin as a slaughter by-product, see MVN 18: 127. 
How these by-products were obtained is not known. Even information about skinning is sparse, ${ }^{22}$ conspicuously omitted also from the Old Babylonian butcher's manual (Foxvog 1989). ${ }^{23}$ Skinning seems to have been of no immediate concern to the state administration and bureaucrats at Puzriš-Dagan; there are only very limited references to animal flayers and none to skinning as such. Neither are other expected livestock management practices documented in the Drehem texts, and moreover, barely any information on how the shepherds organized themselves and their flocks is available.

The consumption of meat ( $\mathrm{uzu}$ ) is likewise poorly documented at Drehem (Lafont 2009: 424). Aja-kala seems to have been responsible for receiving meat. Šulgi-iriĝu is also identified as sending dairy products and meat to the scribe Ur-Baba via ( $\hat{g i r i}_{3}$ ) Zuzu. ${ }^{24}$ The individuals concerned with meat were Aja-kala, Ur-Baba and Dajani, all apparently in the $\mathrm{e}_{2}$-uz-ga (Torino $1: 164$ ) (discussed below).

Occasional references to processed meat ${ }^{25}$ include: preserved/salted meat $(\mathrm{mu}-\mathrm{du}$ lum), ${ }^{26}$ meat to be dried (uzu hadd $-\breve{s}_{3}$, and usually also to be salted), ${ }^{27}$ to be roasted $(\mathrm{ka-izi-še})_{3},{ }^{28}$ to be grilled on charcoal (ne-mur-še ${ }_{3}$ and ne-mur-ta ba-še $\left.{ }_{6}\right),{ }^{29}$ or prepared as broth (uzu a-bala). ${ }^{30}$ Broth was prepared in the $\mathrm{e}_{2}$-uz-ga, ${ }^{31}$ while the salt-

22 For the skinning of a sacrificial animal, see Farber (1977: 57.20, 59.46). There are artistic representations of the process of animal skinning in the Neo-Assyrian period; see for example Layard (1849: Pl. 75).

23 For a discussion on the preparation of an animal for sacrifice, see Scurlock (2006:32-33).

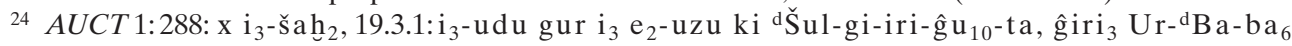
dub-sar mu-kux $($ DU) Zu-zu šu ba-ti.

25 For references to processed meat at Puzriš-Dagan and a brief discussion, see Steinkeller (1995: 49 and ns. 3-7); Sallaberger (1993: 112-113, ns. 510-111, 117); Hilgert (2003: 52-53; 2008: 6 n. 11); Brunke (2011:170-172;186-187).

26 E.g. OIP 115: 280; JCS 14: 107, 2; MVN 15: 101; TRU 117; MVN 13: 443; PDT 2: 1175; Orient 16: 53 (6 sila $_{4}$-ga a-mun-še 3 ), for which, see also Steinkeller (2008: 190 n. 15); Atiqot 4: pl. 10, 55; AUCT 2: 338; AUCT 2: 358; Babyloniaca 7: 75, 4; BCT 1: 39 rev i 6, 11; BCT 1: 107; CST 114; JCS 14: 107, 2; MVN 3: 228 rev. 2; SACT 1: 134; PDT 1: 102 (the last three texts document salted meat that entered the storeroom); $M V N$ 13:443; MVN 15: 95 obv. i 10, ii 14; Nik. 2: 467; NYPL 244; OIP 115: 280; OIP 121: 582; OIP 121: 179; TRU 116; TRU 117; Princeton 2: 432; Princeton 2: 441; MVN 15: 101 ; Ontario 1:113; Akkadica 114-115: 101,27.

27 BCT 1: 39 rev. i 6, 11; JCS 14: 107, 2; MVN 13: 443; Nik. 2: 467; OIP 115: 280; TRU 116; TRU 117; MVN 15:101.

28 PDT 2:1106; TCS 294; AUCT 1:441; BIN 3: 369; Torino 1 252; PDT 2: 1175; CDLB 2008: 2, 6; Ontario 2: 216. For ka-izi, see Hilgert (2003: 77 and n. 257); Sallaberger (1993: 113 and n. 511); Steinkeller (1995: 49, 62 and n.6).

29 According to Steinkeller (1995: 49 and n. 7), this should be translated as 'roasted in hot embers'. Texts mentioning this type of meat preparation are: BIN 3: 369; BIN 3: 74; RA 9: 48, SA 107 (pl.3); TRU 327; Nisaba 8: 188 .

30 E.g. PDT 2: 1106: 1 ud $_{5}$ uzu-a-bala-še 3 ; BPOA 7: 2787; OIP 121: 452; AnOr 7: 154; AnOr 7: 104: obv. 9; AnOr 7: 108, obv. i 5 and 20, ii 2 and 22, rev. v 32, vii 2; DoCu EPHE 274; Ontario 1: 46; ASJ 18: 74, 2; BIN 3:12; BIN 3:369; AUCT 1: 441; TRU 322; TCS 294; TRU 323; BIN 3: 547: obv. 4; PDT 2: 1106 ; NYPL 357; PDT 1: 572; PDT 2: 906; PDT 1: 612; MVN 13: 103; Rochester 86; SET 72; BCT 1: 102 ; AUCT 1:479; PDT 2:1112.

31 In most of the above texts documenting animals to be used for broth, either one of the maškim officials can be shown on the basis of prosopography to have been related to the $\mathrm{e}_{2}$-uz-ga, or the $\mathrm{e}_{2}-\mathrm{uz}-\mathrm{ga}$ is explicitly mentioned. 
ing seems to have been also the responsibility of kitchen officials (e.g. Sulgi-irigu ). ${ }^{32}$ The context within which the expression uzu NIM- še ${ }_{3}{ }^{33}$ occurs suggests a kind of preparation like roasting, as discussed by Hilgert (2008: 6 n. 11).

\subsection{Locations where Dead Animals and By-products Were Managed}

Of the several locations apparently managing dead animals and slaughter by-products, one can distinguish between those concerned with the preparation of food and those used for storage or other management practices. The three locations for food preparation were the kitchen $\left(e_{2}\right.$-muhaldim), the abattoir or slaughterhouse $\left(e_{2}-g u_{4}-g a z\right)$ and the $\mathrm{e}_{2}$-uz-ga. Some Girsu texts treat these three institutions together. ${ }^{34}$ The three places concerned with storage and handling of carcasses and slaughter by-products were the palace $\left(e_{2}-g a l\right)$, the storeroom $\left(e_{2}-k i s ̌ i b-b a\right)$ and the workshop (geš-kin-ti).

Most prominent for the preparation of meat is the kitchen, with more than 1400 references. This is where Puzriš-Dagan officials sent animals that were dead ( $\left.\mathrm{ba}_{-} \mathrm{ug}_{7}\right)$ or destined for slaughter (šu-gid 2 ; discussed above). There also seem to have been several kitchens outside Puzriš-Dagan, such as those at Tummal, ${ }^{35} \mathrm{Ur}^{36}{ }^{36} \mathrm{Nippur}^{37}$ and Uruk, ${ }^{38}$ all seemingly run by Puzriš-Dagan personnel. ${ }^{39}$ The dates of the references to these kitchens outside Puzriš-Dagan correspond closely to the months for the major festivals in those cities, ${ }^{40}$ indicating that they served the royal entourage, including military personnel ( gara $_{3}-\mathrm{du}$ and $\mathrm{aga}_{3}-\mathrm{us}_{2}$ ), who resided there during these festivals.

A cattle slaughterhouse at Puzriš-Dagan is mentioned in Girsu texts, ${ }^{41}$ and although the Drehem texts nowhere refer to an $e_{2}-g_{4}-g a z$, it seems certain that one must have

32 AUCT 2: 358 rev. 5-7: 2(diš) udu niga sag ${ }_{10}$ us $_{2}$ ba-šur ${ }_{2}$ mu-du-lum-še ${ }_{3}{ }^{\text {SŠul-gi-iri-ĝu }}{ }_{10}$ maškim; Ontario 1: 113 obv. 1-4: 1(diš) udu a-lum niga sag 10 us $_{2}$ ba-šur mu-du-lum-še $_{3}$ giri ${ }_{3}{ }^{\mathrm{S}} \mathrm{S} u l-g i-i r i-\hat{g} u_{10}$.

33 ASJ 18: 74, 2; CDLB 2008:2, 6; Torino 1:164; AUCT 1:377; Ontario 2: 216.

34 ASJ 14:334.17, obv. 8-10; MVN 11:95, obv. 12-14; MVN 11:107, obv.12-14; STA 30, obv. 12-14.

35 For e -muhaldim ša $_{3}$ Tum-ma-alki, see SACT 1: 163: 4-6; OIP 121: 419: 4-6; OIP 121: 420: 3-5; OIP 121:421:3-5. Note that the latter tablets refer to the feeding of the gara 3 -du, who were probably stationed at Tummal during the eighth month of AS; Duga, a well-known Puzriš-Dagan official, was in charge of providing for them.

${ }^{36}$ For e -muhaldim ša $_{3}$ Urim $_{5}{ }^{\mathrm{ki}}$-ma, see e.g. YOS 18: 15, obv. 3-5; PDT 2: 1147, rev. 3-6; OIP 121: 427,5-8; MVN 2:164:8-10; Princeton 1:67,4-7; OIP 121:429,5-9.

37 For e ${ }_{2}$-muhaldim ša ${ }_{3} \mathrm{Nibru}^{\mathrm{ki}}$, see e.g. SET 106, obv. 15; BCT 1:35, rev. 25-26; UDT 116, obv. 3 and 5; JCS 57:28, 4, obv. 2 and 4; OIP 121:365, obv. 5 and 7; NYPL 250, obv. 5 and 7.

38 For e 2 -muhaldim ša ${ }_{3} \mathrm{Unu}^{\mathrm{ki}}$, see e.g. NYPL 194; AUCT 1: 890; AUCT 1: 955; Hirose 286; MVN 15: 291; OIP 121:382; OIP 121:383; Ontario 1:81.

39 For a comprehensive discussion of the kitchen at Puzriš-Dagan, see Allred (2006).

40 E.g. at Tummal during the eighth month (Sallaberger 1993: 145); at Ur during the first, seventh and tenth months (ibid.: 179-194); at Nippur during the second (ibid.: 114-122) and twelfth months (ibid.: 150-52). I would like to thank P. Paoletti for bringing this to my attention.

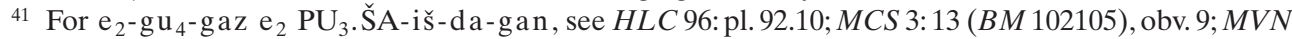
11: 83, obv. 11; $M V N$ 11: 85, obv. 13. See also references to the slaughterhouse in Sagdana in $M V N 5$ : 240, obv. 10; $C T$ 7: 47 (BM 17775), obv. 12. 
operated there. ${ }^{42}$ According to Steinkeller (2008: 190 and ns. 14-17), at Puzriš-Dagan the $\mathrm{e}_{2}-\mathrm{gu}_{4}$-gaz must have been identical to the $\mathrm{e}_{2}$-muhaldim, and many Umma texts seem to use these two terms interchangeably.

The $\mathrm{e}_{2}$-uz-ga, although never explicitly mentioned as receiving dead animals or slaughter by-products, must have been involved in meat preparation as well. Sigrist (1992: 158-162) asserted that it was administered by a cook and served as a residence for elite individuals and the queen, and Sallaberger (1996: 405) has argued that the $\mathrm{e}_{2}$-uz-ga was not a fattening shed. Englund (2002: §4a) suggested that the close association of the $\mathrm{e}_{2}$-uz-ga and the $\mathrm{e}_{2}$-muhaldim in several texts, many of which were published by Uchitel (1996: 223-228), shows that the $e_{2}$-uz-ga was certainly involved with meat preparation. He suggests that the large amount of reed that was sent there indicates a type of smoke house. ${ }^{43}$ For a complete account of the $\mathrm{e}_{2}$ - uz-ga, see Wu (1996).

All those concerned with the administration of the $\mathrm{e}_{2}$-uz-ga at Puzriš-Dagan functioned as maškim, and most held the title of cook: ${ }^{44}$ Aja-kala, ${ }^{45}$ Ur-Baba ${ }^{46}$ and Urim-kidu. Both before and contemporaneously with Aja-kala the cook, texts identify Ba-mu, ${ }^{47} \mathrm{Ur}-$ Šulgira $^{48}$ and Dajani ${ }^{49}$ as maškim officials, apparently responsible for receiving animals destined for the $\mathrm{e}_{2}$-uz-ga. The texts documenting the direct receipt of animals from these people during Šulgi's reign were usually encased in envelopes, some of which are still extant,${ }^{50}$ while later many of them were sealed.

Carcasses and hides were sent to the storeroom ${ }^{51}$ and later removed..$^{52}$ For hides to be stored some preparation would have been necessary, but this is a process not documented in the Ur III texts. ${ }^{53}$ In a few references, mainly from the archive of Šulgi-simti, the palace

42 See the discussions by Steinkeller (2008: 190) and Sharlach (2004: 50-51). For the slaughterhouse at Nippur, see Sharlach (2004:97).

43 See however Johnson (2004: \$3.2), who associates the reeds and mats transferred there with the building of the $\mathrm{e}_{2}$-uz-ga.

${ }^{44}$ For this, see the discussion in Allred (2006: 72-76).

45 Aja-kala is on very few occasions referred to with the title of cook. Even so, it is almost certain that all references to Aja-kala acting as maškim in transactions related to the $\mathrm{e}_{2}$-uz-ga refer to the same Aja-kala. See e.g. ArOr 25: 560, 16; CST 67; MVN 13: 121; PDT 2: 1169; Hirose 48; CST 101; Princeton 1:94, with reference to Nippur; NYPL 123; CST 105; BIN 3: 501.

46 E.g. SAT 2: 551 (ك̌.46.10.15); CST 164; MVN 13: 839; OIP 115: 332.

47 E.g. CTNMC 8; TRU 258; CST 80; BPOA 6:574; MVN 13:116; BIN 3: 612.

48 OIP 115: 232; OIP 115: 371; PDT 1: 119; AAICAB 1/1, Ashm. 1923-426; OIP 115: 381; SACT 1: 136; CST 477.

49 Orient 16: 41, 7; CST 98; Ontario 1:33; CST 125; Nisaba 8: 132; BIN 3: 12; MVN 5: 104; PDT 1: 479; RA $8: 185,3$.

50 See $A u O r$ 8: 82, 4, but also $S A 22$ (Pl. 37), which must have been encased in an envelope, as the top edge of the tablet shows, and $B I N 3: 369 ; B C T 1: 73$, for which one cannot be certain; note also Ontario 1: 36 , which should be collated, since most probably it documents a direct transfer between Nalu and Aja-kala of animals destined for the $\mathrm{e}_{2}$-uz-ga.

51 The phrase used in this kind of transaction was $\mathrm{ad}_{6}$-bi $\mathrm{e}_{2}-\mathrm{kišib}-\mathrm{ba}-\breve{s ̌}_{3} \mathrm{ba}-\mathrm{an}-\mathrm{ku}_{4}$; see $S A T 2$ : 913, rev. 11: 11 udu ba-ug e $_{2}$-kišib-ba-še ${ }_{3} ; N Y P L$ 256: 10 gu $_{4}$ ba-ug e $_{2}$-kišib-ba-še ${ }_{3}$ Beli $i_{2}$-a-ri $i_{2}$-ik šu-ba ti.

52 OIP 115:464: e 2 -kišib-ba-ta.

53 See Levey (1959) for the stages of skin preparation. 
$\left(\mathrm{e}_{2}\right.$-gal) is associated with the storage of hides and carcasses. ${ }^{54}$ Within the central livestock agency, the storage of hides and carcasses at the palace was arranged either through Puzriš-Dagan officials via known scribes of the palace ${ }^{55}$ or directly through well-known Puzriš-Dagan officials. ${ }^{56}$ Why store hides and carcasses at the palace? The palace was probably a full economic unit, a household where several different workshops and craftsmen were operating, and transferring hides there could have been related to such enterprises. Hides were also sent to the workshop (geš-kin-ti), but only a few texts mention this. ${ }^{57}$ The most common expression associated with sending hides to the workshop was kuš-bi ge š-kin-ti-a ba-an-ku ${ }_{4}{ }^{58}$

\subsection{Associated Professions}

Among the professions and titles mentioned in these texts are cooks, flayers, butchers, leather workers, dog handlers and scribes. Only the first four are directly related to processing and preparation. Cooks (muhaldim) are rarely explicitly mentioned in connection with the management of dead animals, although it is almost certain that the officials managing the kitchens at Puzriš-Dagan were cooks by profession and title. Ur-nighar, the official responsible for receiving dead animals during Šulgi's reign (see further below) was indeed a cook, as was his father. His seal (Tsouparopoulou forthcoming: Cat No. 474), impressed on some bullae tagging the contents of tablet sacks as well as on some envelopes recording the receipt of dead animals for the kitchen, explicitly mentions his father's title as mu haldim. Urim-ki-du, another royal cook according to the title on his seal (ibid.: Cat. No. 456), was also responsible for deliveries of animals to be processed at the $\mathrm{e}_{2}$-uz-ga. ${ }^{59}$ Similarly Aja-kala, another person responsible for deliveries to the $\mathrm{e}_{2}-\mathrm{uz}-\mathrm{ga}$, is described as a royal cook on his seal (ibid.: Cat No. 31,32) and in some texts. ${ }^{60}$

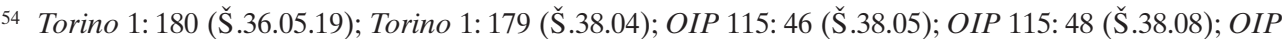

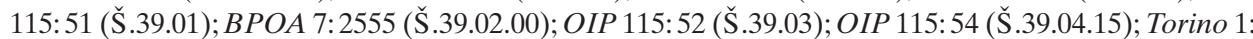

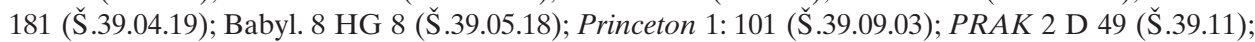

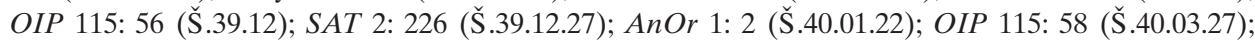

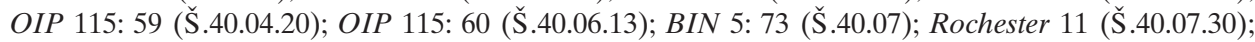

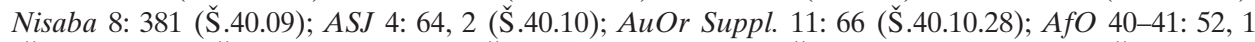

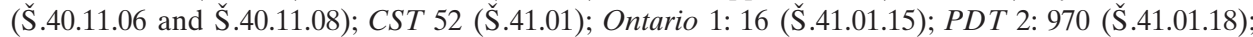
AuOr Suppl. 11: 67 (Š.41.02); Ontario 1:17 (Š.41.05.00); Princeton 1: 98 (Š.41.09.00); AuOr Suppl. 11: 64 (Š.41.09.10); OIP 115: 78 (Š.42.04.03); Hirose 18 (Š.42.08.00); Torino 1: 188 (Š.42.08.28); OIP 115: 80 (Š.42.08.30); OIP 115: 82 (Š 43.01.29); NYPL 079 (Š.43.02.22); OIP 115: 83 (Š.43.03.30).

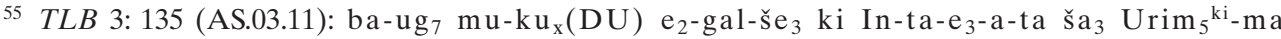
giri ${ }_{3}$ Ur-šu-ga-lam-ma.

${ }^{56}$ AUCT 1: 895 (Š.48.12): ad ${ }_{6}$ ! kuš-bi e 2 -gal-la ba-an-[ku $\left.{ }_{4}\right]$ ki d En-lil ${ }_{2}-l_{2}$-ta ba-zi.

${ }^{57} M V N$ 15:198: kuš gid geš-kin-ti-še $_{3}$.

58 OIP 115: 325, obv. 8, rev. 5; OIP 115: 355 obv. 5; PDT 1: 18, obv. 4; SET 114, obv. 14-18; see also TRU 277, rev. 10: kuš-bi geš-kin ba-an-ku 4 .

59 See above the discussion of the maškim (s) for the $e_{2}$-uz-ga.

${ }^{60}$ An Urdu-Nanna, probably Aja-kala's son, acted in the same capacity. For Urdu-Nanna's seal see Tsouparopoulou (forthcoming: Cat. No. 427). 
Only three flayers (su-si-ig) are named:Atu, Ur-šugalama (Babyl. 8 HG 5 Š.48.05) and Dadaja (JCS 31, 174 F Š.43.06); on a few occasions they receive hides and carcasses. Atu appears in the Early Drehem archives with this title, and his seal also gives his father's title as su-si-ig ( $M V N 3: 147 \breve{S} .35 .03)$. Atu the su-si-ig is mentioned in another Drehem text, dated to Š.43.12 (UDT 121) and in its duplicate $A U C T 1$ 1:235. Dadaja appears in a Drehem text concerned with the transfer of hides (JCS 31175 G Š.43.03), and most probably this Dadaja is identical with the animal flayer. In two Girsu texts the title su-si-ig follows ašg ab (leather worker) ${ }^{61}$ indicating that these two professions were very closely related.

Dog handlers (sipa ur-gir 15 -ra) are regularly mentioned as the recipients of carcasses to feed their dogs. They were attached either to the army (Tsouparopoulou 2012) or to the healing goddess Gula. Butchers ( $\hat{g} \mathrm{ir}_{2}-\mathrm{la}_{2}$ and $\mathrm{gu}_{4}$ - gaz) are rarely mentioned in Ur III texts. Šu-Erra is the only $\mathrm{gu}_{4}$ - $\mathrm{gaz}$ named at Drehem (MVN 15: 275), but the title on his seal is royal cook (muhaldim lugal), and Lafont (2009) assumed that the title $\mathrm{gu}_{4}$-gaz is unattested at Drehem. The leather workers ( $\mathrm{ašgab}$ ) must have been involved with the management of hides, but references to them within the corpus of the livestock agency are almost non-existent.

\section{The Kitchen Department of the Office for Dead Animals}

The three officials associated with this department are:

$\begin{array}{ll}\text { Beli-arik } & \text { Š.42- ̌. } 43 \\ \text { Ur-nighar } & \text { Š. } 43-\text { AS. } 03 \\ \text { Šulgi-iriĝu } & \text { AS.03 - IS.02 }\end{array}$

Once the central agency had been officially established at Puzriš-Dagan (Š.42), Beli-arik was the person who received dead animals from several offices and bureaus of Early Drehem (Naram-ili and Šulgi-simti) and from the central agency. At first he received the animals together with Ur-niĝar, but by Š.44 Ur-nigarar had become the only recipient of dead animals from the central agency's offices. In Š.42.11 both Beli-arik and Ur-niĝar were receiving hides (BIN 3: 611), after which a centralization of this office around Ur-nigar took place, and the first tablet in the available documentation recording such a transfer to Urniĝar alone is dated to Š.44.01. ${ }^{62}$ Ur-niĝar, in turn, was replaced by Šulgi-iriĝu in AS.03.

At first Ur-nigar as the main official used to receive dead animals and hides, but later other officials handled the hides, indicating that there were two departments in the office. The one was for dead animals to be processed for food. The other was for the leather industry, which must have existed at Puzriš-Dagan independently from the shoemaking facility and its archive, ${ }^{63}$ but about which we have little information. Later in Amar-Suena's reign the officials responsible for receiving hides also received wool. ${ }^{64}$

${ }^{61}$ ASJ 20:110, 8: obv. iii 12, rev. i 1 and 19, ii 20; HLC 2: 99 (pl. 93) rev. 20.

62 OIP 115:300. Note that it seems more probable that the official with whom this transaction originated (ki) was Nalu rather than Nasa. Nasa seldom transfers dead animals to this office.

${ }^{63}$ For the leather industry at Puzriš-Dagan, see Stol (1983); and for the shoe archive Paoletti (2012: 127, 133, 183-199, passim).

${ }^{64}$ See also Stępień(1996) for a similar situation at Umma. 
It is suggested here that the three officials Beli-arik, Ur-nighar and Sulgi-iriĝu also manned the kitchen ( $\mathrm{e}_{2}$-muhaldim) at Puzriš-Dagan. The circumstantial evidence for such an affiliation in the texts makes this suggestion almost certain, especially a few texts which state explicitly that Ur-nigar received animals destined for the kitchen. ${ }^{65}$ These are listed in table 1:

Table 1: Texts in which Ur-nighar is associated with the kitchen

\begin{tabular}{|c|c|c|}
\hline Date & Publication & Details \\
\hline Š.43.00.00 & Torino 1:213 & šu-gid ${ }_{2} e_{2}$-muhaldim Ur-niĝargar šu ba-ti \\
\hline Š.43.10.01 & $S A 18(\mathrm{Pl} .28)$ & šu-gid ${ }_{2} e_{2}$-muhaldim-še ${ }_{3}$ Ur-niĝargar šu ba-ti \\
\hline Š. 43.10 .22 & $U C P 9-2-2: 40$ & šu-gid ${ }_{2} e_{2}$-muḩaldim-še ${ }_{3}$ Ur-niĝargar šu ba-ti \\
\hline Š.47.01.12 & $M V N 15: 36$ &  \\
\hline Š.47.08.06 & Engelbert 1 & 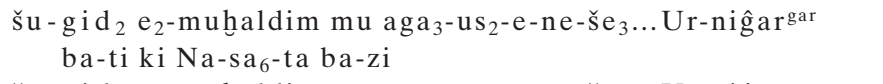 \\
\hline Š.47.08.05 & $\begin{array}{l}M V N 8: 107 \\
(R A 75: 79)\end{array}$ & 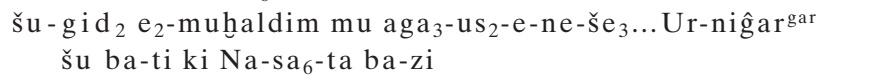 \\
\hline Š.47.08.11 & $\begin{array}{l}\text { Amorites 13: pl. } 5 \\
(\text { OIP } 115: 314)\end{array}$ & 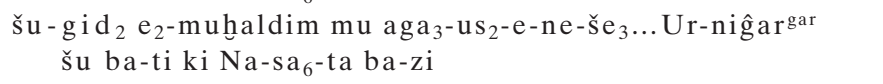 \\
\hline Š. 47.08 .15 & OIP 115:315 & $\begin{array}{l}\text { šu-gid }{ }_{2} e_{2} \text {-muhaldim mu aga }- \text { as }_{2}-e-n e-\check{c}_{3} \ldots \text { Ur-nighargar } \\
\text { šu [ba]-ti ki Na-sa } a_{6} \text {-ta ba-zi }\end{array}$ \\
\hline Š.47.08.22 & $\begin{array}{l}R A 74: 2 \mathrm{a} \\
(O I P 115: 316)\end{array}$ & 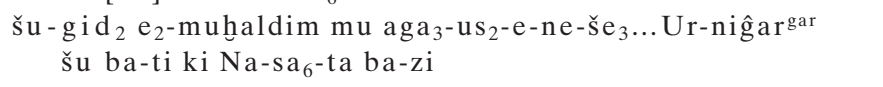 \\
\hline Š.47.09.01 & $M V N 13: 530$ & 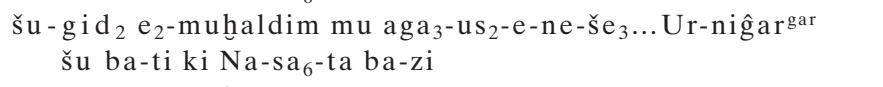 \\
\hline Š.47.09.04 & CST $183^{66}$ & 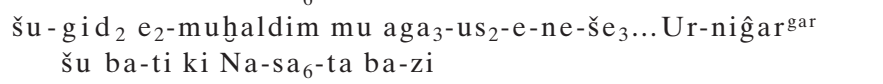 \\
\hline Š.47.09.07 & BIN 3:511 & 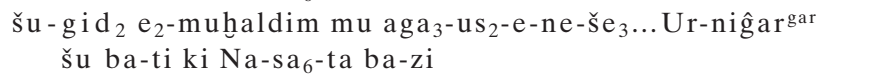 \\
\hline Š.47.10.02 & $\operatorname{CST} 185^{67}$ & 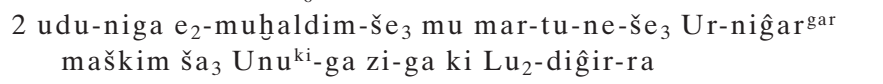 \\
\hline AS.02.01.04 & $S A T 2: 723$ & 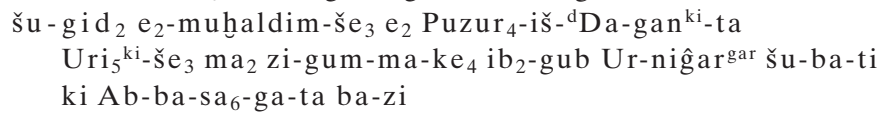 \\
\hline XX.XX.00.05 & JCS 35: 189,1 & 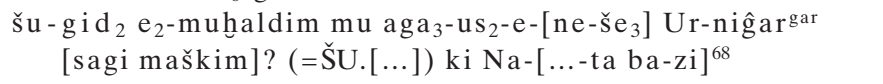 \\
\hline
\end{tabular}

Although there are no direct transfers to Šulgi-iriĝu of animals destined for the kitchen, he appears as maškim or $\hat{g}_{i r i}$ in such transactions, as can be seen from the following texts documenting animals destined for the kitchen under his responsibility (table 2):

65 See also OIP 115: 222 (Š.43.05.12), where Beli-arik functions as maškim for a disbursal to the kitchen for the aga $a_{3}-u_{2}\left(e_{2}\right.$-muhaldim mu aga $a_{3}-u_{2}$-e-ne-še ${ }_{3} B e-l i_{2}-a-r i_{2}-i k$ maškim ziga).

66 Collation MVN 12:p. 102.

${ }^{67}$ Collation MVN 12:p. 102.

68 This tablet should be collated. Most probably it reads: Ur-nighargar šu ba-ti... ki Na-sa ${ }_{6}$-ta ba$\mathrm{zi}$, similar to the previous tablets. 
Table 2: Texts in which Šulgi-iriĝu is associated with the kitchen

\begin{tabular}{|c|c|c|}
\hline Date & Publication & Details \\
\hline AS.04.11.19 & $\begin{array}{l}\text { AOS 32: W64 } \\
(N Y P L 304)\end{array}$ & 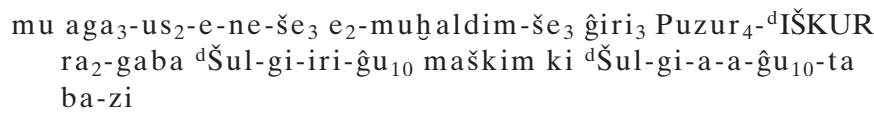 \\
\hline AS.04.11.22 & $\begin{array}{l}R A 9: 51, \\
S A 202(\mathrm{pl} .5)\end{array}$ & 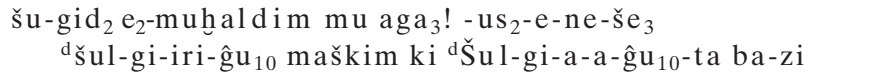 \\
\hline AS.05.06.03 & $S A C T 1: 156$ & 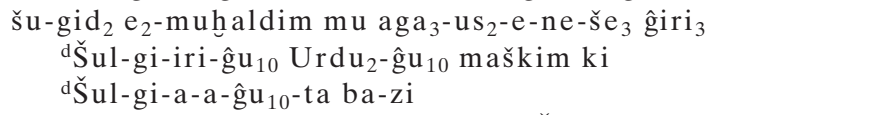 \\
\hline AS.05.06.21 & Nisaba 8: 153 & $\begin{array}{l}\mathrm{e}_{2}-\mathrm{muhal}_{\text {aldim mu kaš }}-\mathrm{ke}_{4}-\mathrm{ne}<\check{\mathrm{s}}_{3}>\mathrm{d} \text { Šul-gi-iri-g } \mathrm{u}_{10} / \\
\text { maškim ki Ur-šu-ga-/lam-ma-ta ba-zi ša }{ }_{3} \mathrm{Unu}^{\mathrm{ki}}-\mathrm{ga} \mathrm{a}_{2}(\mathrm{sic})\end{array}$ \\
\hline AS.06.08.26 & OIP 121: 470 & 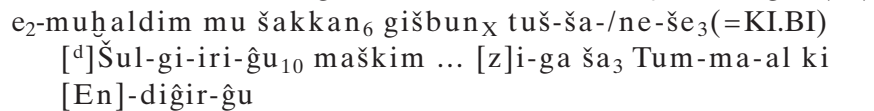 \\
\hline AS.06.11.04 & PDT 2:1082 & 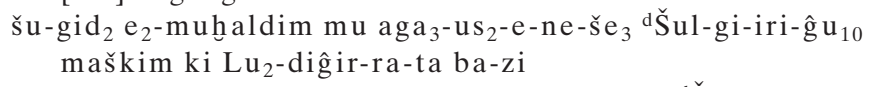 \\
\hline AS.06.11.27 & Nisaba 8:36 &  \\
\hline AS.06.12.24 & $T L B 3: 31$ & 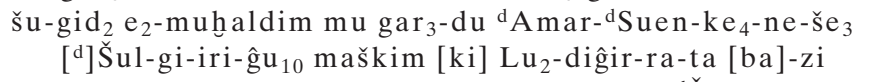 \\
\hline AS.07.06.06 & BPOA 7:2564 & 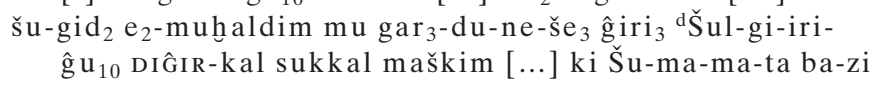 \\
\hline AS.08.01.18 & BIN 3: 477 & 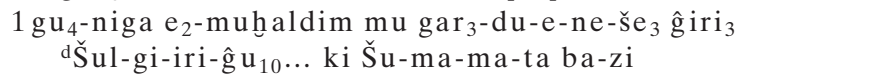 \\
\hline AS.08.04.15 & PDT 2:951 & 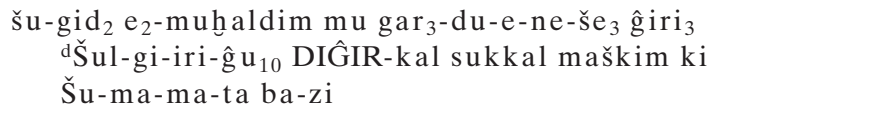 \\
\hline AS.08.05.28 & $M V N 15: 204$ & 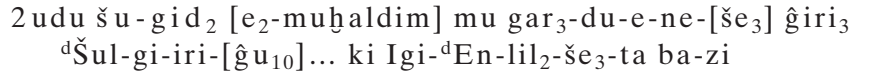 \\
\hline AS.08.07.27 & $\begin{array}{l}A O S 32: 08 \\
(N Y P L 244)\end{array}$ & 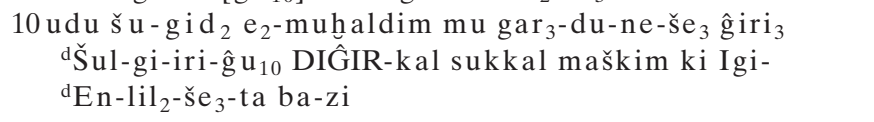 \\
\hline XXXX.00.00 & $M V N 11: 144$ & 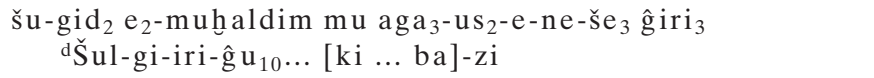 \\
\hline
\end{tabular}

\subsection{The Official Beli-arik $(\check{S} .42-\breve{S} .43)$}

Beli-arik the 'cupbearer' ( sagi) was connected with the receipt of dead animals and carcasses at Puzriš-Dagan from Š.42. His seal is of the royal servant type, mentioning King Šulgi as his lord (Tsouparopoulou forthcoming: Cat. No. 53). He first received carcasses together with Ur-nighar in Š.42.11, sent by Naram-ili (BIN 3: 611 and Sumer 24: 71, 7). A month later he received dead oxen from Enlila, designated for the storage room. ${ }^{69}$ In the same month Beli-arik, together with Ur-nighar, received the carcasses of dead animals from Naram-ili ( $A O S$ 32, S05 NYPL 278), recorded on a tablet encased in an envelope; the envelope was sealed by both Beli-arik and Ur-nighar.

69

$\operatorname{AOS} 32, \mathrm{O} 24: \mathrm{e}_{2}$-kišib-na-š $\mathrm{e}_{3}$. 
Beli-arik's first clear association with the central livestock agency can be found in $\breve{S} .43$, when he received dead animals from Ašniu of the Tummal branch. ${ }^{70}$ Other transfers from Ašniu to Beli-arik followed, ${ }^{71}$ and he also acted as the maš kim official in an expenditure document of an unknown official for dead animals given to the kitchen for the $\mathrm{aga}_{3}-\mathrm{us}_{2}$ (OIP 115: 222 Š.43.05.12). That was his last transaction associated with the office for dead animals. Thereafter, Ur-nighar took over, and eventually he controlled all the transfers of dead animals during the reign of Šulgi and the first three years of Amar-Suena.

\subsection{The Official Ur-nighar (̌̌.43-AS.03)}

Ur-nighar's name figures in more than 800 documents from Drehem. According to his seal he was the son of Tiru the cook (Tsouparopoulou forthcoming: Cat. No. 474). In Š.42 and $\breve{S} .43$ he received dead animals and carcasses together with Beli-arik the cupbearer, but after Š.43.09 he remained alone in the post. ${ }^{72}$ The animals that passed through his bureau were almost always explicitly described as dead (ba-ug $\left.g_{7}\right)$ or for slaughter $\left(\breve{s} u-g d_{2}\right)$ and must have been sent to the kitchen, although this is not explicitly mentioned in the texts. ${ }^{73}$

Ur-nigar received dead animals mainly from one office, the disbursal office. Hundreds of tablets document his receipt of dead animals from Nalu (of the Ur/Nippur branch) ${ }^{74}$ from Ahuni and Lu-digirira U-H (from the nakabtum branch), from En-digirĝ for Tummal, ${ }^{75}$ and from officials of the branch for rare/exotic animals, most notably Lu-digirira I-Š, as well as dead equids from $\breve{S}$ u-Idim.

Ur-nighar sealed a tablet dated to Š.48 for the receipt of dead animals from Lu-digira (SAT 2: 573, Š.48.07) over a period of a month. According to this tablet, the number of animals received by Ur-nighar from the bureau of Lu-digirira (possibly U-H) is 473 (463 ovine and 10 cattle). Lu-digira seems to have sent about 15 animals every day to the office for dead animals. This tablet, sealed by Ur-nighar, documented his receipt of animals for a whole month, but such texts are rare within the office for dead animals. Obviously they did exist and their rarity is probably due to the chance preservation of such tablets. A similar docu-

70 TCS 132 (Torino 1:268), dated to Š.43.02.22.

71 MVN 13: 861 (Š.43.02.28); RT 37: 1361 (Š .43.02.30); RA 9: 40, SA 1 (pl. 1) (Š.43.03.08); AnOr 1: 5 (Š .43.03.14); Sumer 24: 72, 8 and TIM 6: 28 (Š.43.04.02); Nisaba 9: 190 (Š.43.05.10); RA 9: 40, SA 2 (Š.43.06.24).

72 The first tablet documenting him alone receiving carcasses from Naram-ili is apparently $B I N$ 3: 6 , dated to Š.43.09.

73 During Šulgi's reign, especially from Š.47, another person appears with the same name, who also received dead animals. That person was a dog handler and received the carcasses of dead animals to feed the dogs for which he was responsible (e.g. SACT 1:127, rev. 13-14). It is sometimes difficult to differentiate between these two men, who were clearly not identical, since Ur-nigar, the official of the office for dead animals, was not responsible for receiving animals destined for the dogs. Usually the phrase $\mathrm{e}_{2}$-kišib (storeroom) was used in connection with the dog handler, e.g. SA 49 (Pl.5), OIP 115: 325; but see tablet $A O S$ 32: O 24, where Beli-arik received dead oxen designated as $\mathrm{e}_{2}-\mathrm{kišib}-\mathrm{n} \mathrm{a}-\mathrm{s}_{\mathrm{e}}$. Thus, some references to Ur-nigar in connection with carcasses probably refer to the dog handler and not the official of the office for dead animals.

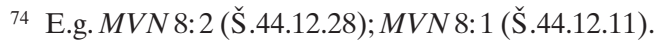

75 E.g. $M V N 20: 182$ (Š.45.03.27); $A O S$ 32: G13 (Š.45.07.15). 
ment must be $B R M$ 3: 42, recording En-digiirĝu's transfers of dead animals to Ur-nighar, which he also sealed. ${ }^{76}$ However, this document is a bulla, used as a tag for a container of the corresponding tablets. It is thus possible that $S A T 2: 573$ is also a bulla, used to tag a leather bag containing the tablets documenting receipts of dead animals by Ur-nigar from Lu-diĝira. ${ }^{77}$

Generally, the tablets documenting such transfers to the office for dead animals during the reign of Šulgi did not have a left-edge inscription. A few, however, did, and in these cases, the scribe recorded the year-name there. In the reign of Amar-Suena, especially after the third month of his second regnal year, some scribes started using the left-edge to write the total number of animals transferred to the office for dead animals, ${ }^{78}$ seen most prominently in tablets originating from the bureau of Lu-digira. This became a common practice in the other offices also. ${ }^{79}$

During the reign of Amar-Suena, Nanna-andul is involved with Ur-nigar in the receipt of dead animals, mostly acting as the sealer of the pertinent documents. ${ }^{80}$ The bullae and envelopes he sealed are transfers of dead animals to Ur-nighar. One is from Abba-saga, the chief official; ${ }^{81}$ the other is a bulla with a monthly account of the animals that Lu-digira I-Š sent to Ur-nighar ( $M V N$ 4:117, AS.02.08); the last one is a bulla documenting a transfer from Abba-saga of animals that had died at Tummal (ASJ 19: 204.14, AS.02.09). All envelopes and bullae date to the second year of Amar-Suena's reign. In those cases in which

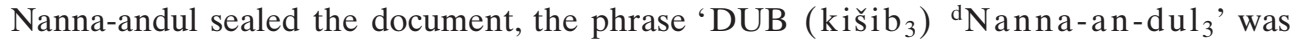
always recorded in the text, ${ }^{82}$ although his exact position within the Puzriš-Dagan central agency cannot be easily determined. The last tablet we have for Ur-nighar receiving dead animals was issued in AS.03.04.06 (Nisaba 8:243). From then on, Šulgi-iriĝu takes over that responsibility.

The disbursal office and the chief official's office sent dead animals destined for the kitchen to Ur-nighar, either directly by issuing a transfer ( $\breve{u}$ ba-ti) document or indirectly by recording a transfer in a double-entry expenditure document (ba-zi/zi-ga). However, no direct transfers from the shepherds' office exist for the period that Ur-nigar officiated at the department for the kitchen, including during Šulgi's years. This does not mean that the shepherds' office did not have an obligation to send their animals there, but it could be explained by the appearance of expenditure documents from the chief official's office. The same animals transferred to the kitchen, which Ur-nighar received (šu ba-ti) after they were debited from the account (ba-zi) of Nasa the chief official, are found to have been previously distributed by Ur-ku-nuna on the same day, in documents which only bear the designation $\mathrm{e}_{2}$-muhaldim. The following is an example with both tablets dated to the same day ( $\breve{S} .47 .08 .11)$; the outlined text represents parallel passages:

76 Dated to AS.01.

77 For more information on these types of bullae, see the author's forthcoming article on archival practices at Puzriš-Dagan.

78 E.g. Ontario 1:120 (AS.02.03.07); Nisaba 8:117 (AS.02.03.19); TCS 197 (AS.02.04.11).

79 For a discussion of left-edge inscriptions, see Watson (1986) and Hilgert (2003).

${ }^{80}$ For his seal, see Tsouparopoulou (forthcoming: Cat. No. 281).

${ }^{81}$ Envelope of $\mathrm{OrSP}$ 47-49:131 (AS.02.07.20).

${ }^{82}$ MVN 4:117 (AS.02.08); ASJ 19:204.14 (AS.02.09). 
[A] OIP 115:314

Obv.

1. 1 sila $_{4}$-niga ${ }^{\mathrm{d}} \mathrm{En}-\mathrm{lil}_{2}$

2. $m u-k u_{x}(D U) U r-n i g h a r g a r$

3. 1 sila $_{4}{ }^{\mathrm{d}} \mathrm{Nin}-\mathrm{lil}_{2}$

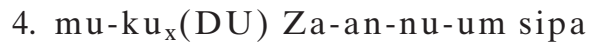

5. zabar-dab ${ }_{5}$ maškim

6. $1 \mathrm{maš}_{2} \mathrm{e}_{2}$-uz-ga

7. $m u-k u_{x}(D U) K u-n a-[m a]-t u m / m a r-t u$

8. A-a-kal-la maškim

9. $3 \mathrm{gu}_{4} 3 \mathrm{ab}_{2}$

Rev.

10. $13 \mathrm{udu} 15 \mathrm{u}_{8}$

11. $2 \mathrm{ud}_{5}$ šu-gid $2 \mathrm{e}_{2}$-muhaldim

12. $\mathrm{mu} \mathrm{aga}-\mathrm{us}_{2}-\mathrm{e}-\mathrm{ne}-\mathrm{še}_{3}$

13. Ur-niĝargar šu ba-ti

15. $\mathrm{u}_{4} 11-\mathrm{kam}$

16. $\mathrm{ki} \mathrm{Na}-\mathrm{sa}_{6}-\mathrm{ta}$

17. ba-zi

18. iti šu-eš-ša

19. mu us ${ }_{2}-\mathrm{sa} \mathrm{Ki}-\mathrm{maš}{ }^{\mathrm{ki}} / \mathrm{ba}-\mathrm{h} u l$
[B] AUCT 1:876

Obv.

1. $13 \mathrm{udu}$

2. $15 \mathrm{u}_{8}$

3. $2 \mathrm{ud}_{5}$

4. $\mathrm{e}_{2}$-muhaldim

5. $\mathrm{u}_{4} 11-\mathrm{kam}$

Rev.

6. zi-ga

7. ki Ur-ku $u_{3}-n u n-n a$

8. iti šu-ešs-ša

9. mu us ${ }_{2}-\mathrm{sa} \mathrm{Ki}-\mathrm{maš}{ }^{k i}$ ba-ḩul

[A] "1 barley-fed lamb (for) the god Enlil: delivery of Ur-nighar. 1 lamb (for) the goddess Ninlil: delivery of Zannum the shepherd. The $\mathrm{zabar-d} \mathrm{ab} \mathrm{b}_{5}$ (was) the requisitioner.

1 goat (for) the $\mathrm{e}_{2}$-uz-ga: delivery of Kuna-matum the Westerner. Aja-kala (was) the requisitioner.

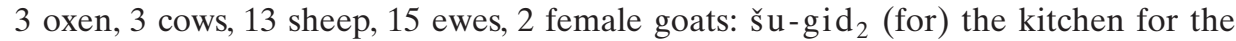
guards. Ur-nighar received (them).

On the $11^{\text {th }}$ day disbursed from Nasa. Month of Šueša. Year after (the year) Kimaš was destroyed."

[B] "13 sheep, 15 ewes, 2 female goats (for) the kitchen.

On the 11th day withdrawn from Ur-ku-nuna. Month of Šueša. Year after (the year) Kimaš was destroyed.”

These documents could perhaps indicate that Ur-ku-nuna routed the corresponding animals first to Nasa, and that Nasa was then responsible for distributing them. This procedure was not only prevalent with regards to animals sent to the kitchen from the bureau of Ur-ku-nuna, but for all of Ur-ku-nuna's expenditures (zi-ga/ba-zi). The tablets below, both dated to $\breve{S} .47 .08 .22$, show this: 
[A] $R A$ 74:2 a (OIP 115:316)

Obv.

1. 1 sila $_{4}{ }^{\mathrm{d}} \mathrm{Utu}$

2. $m u-k u_{x}(D U)$ Ad-da-tur

3. 1 sila $_{4} \mathrm{mu}^{-k u_{\mathrm{x}}}(D U)$ Šu-d Nin-šubur

4. 1 sila $_{4}$ mu-ku $_{\mathrm{x}}(\mathrm{DU})$ Ur-niĝargar

5. ${ }^{\mathrm{d}}$ Inana

6. zabar-dab ${ }_{5}$ maškim

7. 1 amar maš-da $a_{3} e_{2}-u z-g a$

8. $m u-k u_{x}(D U)$ ensi ${ }_{2} \mathrm{Mar}_{2}-\mathrm{da}^{\mathrm{ki}}$

9. A-a-kal-la maškim

10. $1 \mathrm{gu}_{4} 6 \mathrm{udu} 4 \mathrm{maš}_{2}$

11. nig $_{2}$-mussa( $\left.\mathrm{sa}_{2}\right)$ Ri-is-DIĜIR/ sa 12 -ti-um

Rev.

12. $\left[\mathrm{e}_{2}\right.$ ?] Da-a-a-ni muhaldim-š $\mathrm{e}_{3}$

13. $\mathrm{Urdu}_{2}-\hat{\mathrm{g}} \mathrm{u}_{10}$ maškim

14. $2 \mathrm{gu}_{4} 4 \mathrm{ab}_{2}$

15. 8 udu $20 \mathrm{u}_{8} 2 \mathrm{ud}_{5}$

16. šu-gid $\mathrm{e}_{2}-\mathrm{e}_{\mathrm{h}} \mathrm{haldim} \mathrm{mu} \mathrm{aga}_{3}-1$ us $_{2}$-e-ne-še 3

17. Ur-niĝargar šu ba-ti

18. $\mathrm{u}_{4} 22-\mathrm{kam}$
[B] $M V N$ 8:108

Obv.

1. $6 \mathrm{udu} 4 \mathrm{mas}_{2}$

2. nig $_{2}$-mussa( $\left.\mathrm{sa}_{2}\right) \mathrm{Ri}$-is-DIĜIR

3. $8 \mathrm{udu} 20 \mathrm{u}_{8}$

4. $2 \mathrm{ud}_{5}$

Rev.

5. $\mathrm{e}_{2}$-muhaldim $\mathrm{u}_{4} 22-\mathrm{kam}$

6. zi-ga ki Ur-ku $u_{3}-n u n-n a$

7. iti šu-ešs-ša



19. ki Na-sa ${ }_{6}$-ta ba-zi

20. iti šu-eš-ša

21. mu us ${ }_{2}$-sa Ki-maški/ba-hul

[A] "1 lamb (for) the god Utu: delivery of Adda-tur. 1 lamb: delivery of Šu-Ninšubur; 1 lamb: delivery of Ur-niĝar; (for) the goddess Inana. The zabar-dab ${ }_{5}$ (was) the requisitioner.

1 gazelle fawn: delivery of the governor of Marad. Aja-kala (was) the requisitioner. 1 ox, 6 sheep, 4 goats: betrothal gift of Ris-ilum the Easterner for the house of Dajani the cook. Urdu-ĝu (was) the requisitioner.

2 oxen, 4 cows, 8 sheep, 20 ewes, 2 female goats: šu-gid 2 (for) the kitchen for the guards. Ur-niĝar received (them).

On the $22^{\text {nd }}$ day expended from Nasa. Month of Šueša. Year after (the year) Kimaš was destroyed."

[B] "6 sheep, 4 goats: betrothal gift of Ris-ilum.

8 sheep, 20 ewes, 2 female goats: (for) the kitchen.

On the $22^{\text {nd }}$ day withdrawn from Ur-ku-nuna. Month of Šueša. Year after (the year) Kimaš was destroyed."

This administrative peculiarity indicates that there was close cooperation between the office of the chief official and that of the shepherds, while the officials of the disbursal of- 
fice were working independently of the chief official. Only later, for the closing of their accounts, were the officials of the disbursal office obliged to report to the chief official's office.

\subsection{The Official Šulgi-irighu (AS.03 - IS.02)}

Šulgi-irighu headed the office for dead animals from AS.03 until the central agency ceased to function, and about 900 extant tablets document his receipt of dead animals from several officials of the disbursal office, mainly from the branches of the nakabtum, Tummal and Ur/Nippur (see figure 1). Since it is not possible to cite all the relevant texts here, a few examples will be given regarding his transactions.

He received animals in the same way as had his predecessor Ur-nigar and from the same bureaus: from Šu-Idim and later from Šu-Erra, perhaps Šu-Idim's son, dead equids, ${ }^{83}$ from Nalu (of the Ur/Nippur branch); ${ }^{84}$ from Šulgi-ajaĝu, ${ }^{85}$ Lu-digira I-Š and Ahu-Wer ${ }^{86}$ of the nakabtum branch; from En-digirg $\hat{\text { gu }}$ of the Tummal branch, ${ }^{87}$ and later from Kurub-ilak; ${ }^{88}$ from Turam-Dagan and Uta-mišaram of the branch for the royal court; ${ }^{89}$ and from officials of the branch for rare/exotic animals, most notably Lu-digirira U-H (CST 277; Hirose 151).

In AS.05, when Šulgi-iriĝu started receiving dead animals from the officials of the branch for the royal court (Turam-Dagan and Uta-mišaram), several ĝiri ${ }_{3}$ officials associated with the officials of that branch were named in the transfers..$^{90}$ This had nothing to do with the office for dead animals, but was associated with that particular branch of the disbursal office. The same can be seen with Ahu-Wer during ŠS.02; two officials who are associated with Ahu-Wer's bureau at the disbursal office (Ur-lugal-banda and Ur-uš-gida) are seen acting as $\hat{\text { giri }}{ }_{3}$ in Ahu-Wer's transfers to Šulgi-iriĝu. ${ }^{91}$ Moreover, most of the sealed documents involved with this office were sealed by officials working closely with the sender, such as Duga, Hulal and Ahu-waqar on behalf of Ur-ku-nuna. Some other sealing officials such as Nur-Suen, were associated with the chief official's office. The sealed tablets originating from the bureaus of Ur-ku-nuna or Intaea were sealed by Ur-Šulpae. Babati, the maternal uncle of ŠS, sealed most of the archival labels (bullae) associated with transfers of dead animals from officials of the disbursal office to this department during this period. ${ }^{92}$ For example, we have such bullae sealed by Babati for monthly accounts of En-digirirgu for the sixth month of AS.06 (PDT 1:398), for transfers of Turam-Dagan for the

83 E.g. Nisaba 8:305; Torino 1:330; OIP 121:500; Nisaba 8: 229.

84 E.g. Nisaba 8: 253; Hirose 146; ASJ 11:324, 10.

85 Ontario 1: 122; MVN 2:330; JCS 46: 19, 2; DoС СР EPE 310.

86 E.g. Ontario 1: 124; JCS 52:9, 21; MVN 13: 74; CST 279; BCT1: 8.

87 BPOA 7:2989; BPOA 7:2704; PDT 2:1137; AUCT 1:831.

88 Note that Torino 1:378 should be dated to ŠS.02.

89 Always with a ra-gaba acting as giri $i_{3}$; see TCS 138.

90 E.g. TCS 138 (AS.05.00.22); OIP 121:520 (AS.05.02.19).

91 E.g. BCT1:21; BCT1:22; Nisaba 8:351.

92 For his seal, see Tsouparopoulou (forthcoming: Cat. No. 48) and references to pertinent bibliography therein. 
seventh month of AS.06 (NYPL 354), as well as for those of Ahu-Wer (BRM 3: 37, ŠS.06.05), Sukalli (BRM 3:38, ŠS.06.11), Nur-Suen (PDT 2:1200, ŠS.07.03) and others.

Another monthly account is $M V N$ 13: 910, which documents the transfer of 34 dead ovines from the bureau of Ahu-Wer that Šulgi-iriĝu took in charge. This document was in all probability a bulla attached to the container of the pertinent tablets from the bureau of Ahu-Wer for the ninth month of AS.04. This object was impressed with the seal of LuNanna, the son of Inim-Šara, reminiscent of the patronymic of the previous holder of the same office in the nakabtum branch, Lu-digira.${ }^{93}$ Interestingly, we have none of the pertinent tablets documenting such a transfer from Ahu-Wer's bureau for this period.

After ŠS.07, Ur-ku-nuna of the shepherds' office transferred animals to the office for dead animals. Before that date, transfers of dead animals from officials belonging to the shepherds' office are not attested (see figure 1). Ur-ku-nuna always appears in these transactions with a giri $_{3}$ official, such as Nur-Adad, Hulal or Lu-šalim; after Ibbi-Suen, from among the officials Ahu-waqar, Duga and Nūr-Suen, two of them act as ĝiri $i_{3}$. These ĝ iri $_{3}$ officials were not associated with the office for dead animals itself but with the officials who had sent the dead animals to Šulgi-iriĝu. ${ }^{94}$

\section{The Department of Hides and Carcasses}

In this separate department dealing with the carcasses, hides and other by-products within the office for dead animals, Nur-Suen officiated from AS.01 until ŠS.04, and Lu-kala from ŠS.05 until IS.02. Both were also associated with the processing of wool and textiles.

During Šulgi's reign Beli-tab ${ }^{95}$ was responsible, as seen in Šulgi-simti's archive, for receiving the hides and carcasses of several animals. In Š.42, Ur-nigarar, the official in the department for dead animals for the kitchen, received together with Beli-arik the cupbearer (sagi) carcasses and hides on three occasions, as will be seen below. But with AmarSuena's ascent to the throne an official named Nur-Suen started receiving them exclusively, independently of Ur-nigarar's bureau. Lu-kala assumed this task in ŠS.04. Closely associated with these two officials were people designated as 'carcass disposers' or 'animal flayers', such as Atu, Dadaja and Ur-šugalama. They received what was left of the carcasses of dead animals from dog handlers after the dogs had had their fill. They also occasionally received animal skins and carcasses from Nur-Suen and later Lu-kala (Cooper 1979; Tsouparopoulou 2012).

The office for dead animals not only directed dead animals to the kitchen but was also responsible for disposing of the carcasses of slaughtered animals and perhaps also processing them. The evidence that exists at Drehem for the management of these by-products, such as skins and carcasses, will now be discussed. Interestingly none of the documents concerned with transfers and distribution of skins, carcasses and other by-products are dated by the day, in contrast to all the documents related to the management of dead animals.

93 See also MVN 15:320, of the same date (AS.04.09), a transfer of 34 cattle and 126+ sheep from Intaea to Šulgi-iriĝu, mentioning k išib 3 (= DUB) Lu-Nanna.

${ }_{94}$ For these officials see Tsouparopoulou (forthcoming).

95 For his seal, see Tsouparopoulou (forthcoming: Cat. No. 55). 


\subsection{Management of Slaughter By-products during Šulgi’s Reign}

During Šlgi's reign the management of hides and carcasses within the Puzriš-Dagan central agency was less clearly structured. However, we have a single text, OIP 115: 325

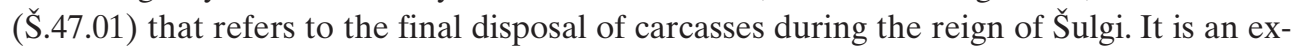
penditure document of Nasa, the chief official, which mentions carcasses given to weavers for food, ${ }^{96}$ carcasses that Ur-nighar received for the storeroom ${ }^{97}$ and hides given to the workshop. $^{98}$

Even though there is less evidence for the management of the slaughter by-products during this period, three people were consistently involved: Ur-nighar from the office for dead animals, the chief official Nasa and Naram-ili. During Šulgi's reign, Naram-ili once sent more than 17,000 hides and 1200 carcasses to Lugal-ša ${ }_{4}-[\mathrm{ga}]-\mathrm{su}_{3}$ (PDT 1:388), and on another occasion he transferred over 5000 carcasses to Ur-nighar (Princeton 1:118). The pertinent documents are presented in table 3.

\subsection{The Official Nur-Suen}

During Amar-Suena's reign, especially from AS.02 onwards, the distribution of hides and carcasses was organised around just one man, Nur-Suen (table 4). Until then the management was partly under Ur-nigar, the head of the office for dead animals, and partly under Naram-ili. Ur-nigar received all the dead animals, most probably destined for the kitchen, but from AS.02 onwards he no longer received any by-products. Naram-ili appears sporadically dealing with hides until AS.03, but from AS.01.03 until ŠS.03.11 it is Nur-Suen who deals with hides, carcasses and tendons. Nur-Suen never handled animals described as ba- $\mathrm{ug}_{7}$, which implies that he was responsible only for by-products. Veldhuis (2008) has very convincingly shown that in all the tablets stemming from Nur-Suen's bureau the scribe consistently wrote $\mathrm{ad}_{6}\left(\mathrm{LU}_{2} \times \mathrm{BAD}\right)$ to denote carcasses.

At the beginning and until $\breve{S} .47$ this bureau had close connections with the archive of Naram-ili, then later with the dog handlers working for the army (Tsouparopoulou 2012) and those related to Gula. Two phrases are found often in relation to this department: $\mathrm{e}_{2}$-kišib-ba-š $\mathrm{e}_{3}$ ba-an-ku$u_{4}$ (brought into the storeroom) in texts of the chief official Nasa, and $e_{2}$-gal-la ba-an-[ $\left.\mathrm{ku}_{4}\right]$ (brought into the palace) in texts from Enlila's bureau of the shepherds' office.

Nur-Suen's responsibilities seems to be have been similar in some respects to those of Naram-ili earlier. He also dealt with many equids as well as with textiles and wool from AS.02,99 and once he transferred a large number of hides to Puzur-ili, the head of the leather workshop at Puzriš-Dagan. This is reminiscent of Naram-ili's dealing with the leather workshop at Puzriš-Dagan (JCS 35:184,2).

${ }^{9} \mathrm{ad}_{6}$ ?-bi $12-\mathrm{am}_{3}$ geme $_{2}$ uš-bar e ${ }_{2}$-amar d ${ }^{\mathrm{S} u l-g i-r a-k e_{4} \text { ba-ab-gu }}$.

${ }_{97} \mathrm{ad}_{6}$ ?-bi $20 \mathrm{la}_{2} 1-\mathrm{am}_{3} \mathrm{e}_{2}$-kišib-ba-še 3 Ur-nighargar šu ba-ti.

${ }_{98} \mathrm{kuš-bi} \mathrm{geš-kin-ti-a} \mathrm{ba-an-ku}{ }_{4}$.

99 CST 239 (AS.01.10); TRU 304 (AS.01.11); JEOL 26: 52, 15 (AS.02.08); PDT 1: 421 (AS.02.12); MVN 13: 11 (AS.03.08); AAICAB 1/1, Ashm. 1924-0553 (AS.03.08); JCS 52: 9, 23 (AS.04.09); OIP 121: 502 (AS.04.12); BPOA 7: 2854 (AS.08.09); Princeton 2: 438 (ŠS.03.02); SAT 3: 1274 (ŠS.02.08.10); ASJ 19: 208, 26 (ŠS.03.03.20); PDT 1: 624 (ŠS.03.04); BIN 3: 563 (ŠS.03.04); AUCT 3: 351 (ŠS.03.04.19). 
Even though he seems to have been replaced by Lu-kala in ŠS.04, Nur-Suen continued acting as $\hat{\mathrm{gir}} \mathrm{i}_{3}$ in Lu-kala's transactions. In one text he is mentioned as a scribe of the palace (dub-sar e $e_{2}$ gal) (PDT 2:1073). Similarly, the scribe Nur-Suen, who acted as $\hat{g} i_{1} i_{3}$ and sealer in many of the transactions of the chief officials' office and other bureaus starting from the last years of Amar-Suena's reign and continuing well into the reign of Ibbi-Suen, could be the same Nur-Suen. This would mean that his position was simply managerial and did not require any affiliation to a specific group or profession. It is to be compared to the position of Ur-nighar of the department for the dead animals for the kitchen, or the positions of the intermediaries between the shepherds and the state. Nur-Suen was just one more scribe and bureaucrat who could do equally well in a department managing wool, skins and carcasses or in a department checking and writing tablets documenting everyday transactions of transfers of live animals.

\subsection{The Official Lu-kala}

Until ŠS.03 Nur-Suen continued dealing with hides and carcasses. But from ŠS.04 (MVN 15: 298), and more consistently from ŠS.07, Lu-kala appears to be associated with these by-products. Lu-kala mostly dealt with wool, ${ }^{100}$ and in his documents Nur-Suen and Nanna-

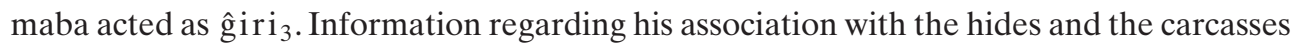
comes mainly from long annual accounts of other officials (sporadically from daily accounts), but this is enough to classify him as the successor to Nur-Suen's office. Based on the information given in Table $5^{101}$ it is easy to speculate that there are no pertinent tablets documenting the dealings of Lu-kala with hides and carcasses, although it is evident from the monthly and annual accounts that he was indeed involved in such business. As mentioned previously, the sign $\mathrm{ad}_{3}(\mathrm{UDU} \times \mathrm{BAD})$ to indicate a carcass was introduced by the scribes working in Lu-kala's office (Veldhuis 2008).

100 BPOA 7: 2513 (ŠS.04.04.05); AUCT 3: 192 (ŠS.04.08.29); AUCT 3: 212 (ŠS.04.09.26); AUCT 3: 191 (ŠS.04.12.21); PDT 1:312 (ŠS.04.12.24); Princeton 1: 550 (ŠS.05.03.22); BIN 3:356 (ŠS.05.07.28);PDT 1: 490 (ŠS.05.08.18); Nisaba 8: 379 (ŠS.05.13); BIN 3: 455 (ŠS.07.06.23); MVN 18: 385 (ŠS.07.07.03+); BPOA 6: 1470 (ŠS.07.08.29); AUCT 3: 361 (ŠS.08.06.04); AUCT 3: 209 (ŠS.08.09.16); RA 80: 12, 8 (ŠS.08.10.07); JCS 52: 11, 49 (ŠS.09.06); $M V N$ 13: 45 (ŠS.09.08.22); $M V N$ 13: 46 (ŠS.09.08.24); PDT 2: 1058 (ŠS.XX.00.06); TAD 63 (IS.01.03.28); BPOA 6: 790 (IS.01.09.06).

101 Only the tablets for which we have enough information to place them within an office are included here. For other texts dealing with hides and carcasses, see Veldhuis (2008) and TRU 14; AUCT 2: 195; NABU 2002: 76; PDT 1:515. 


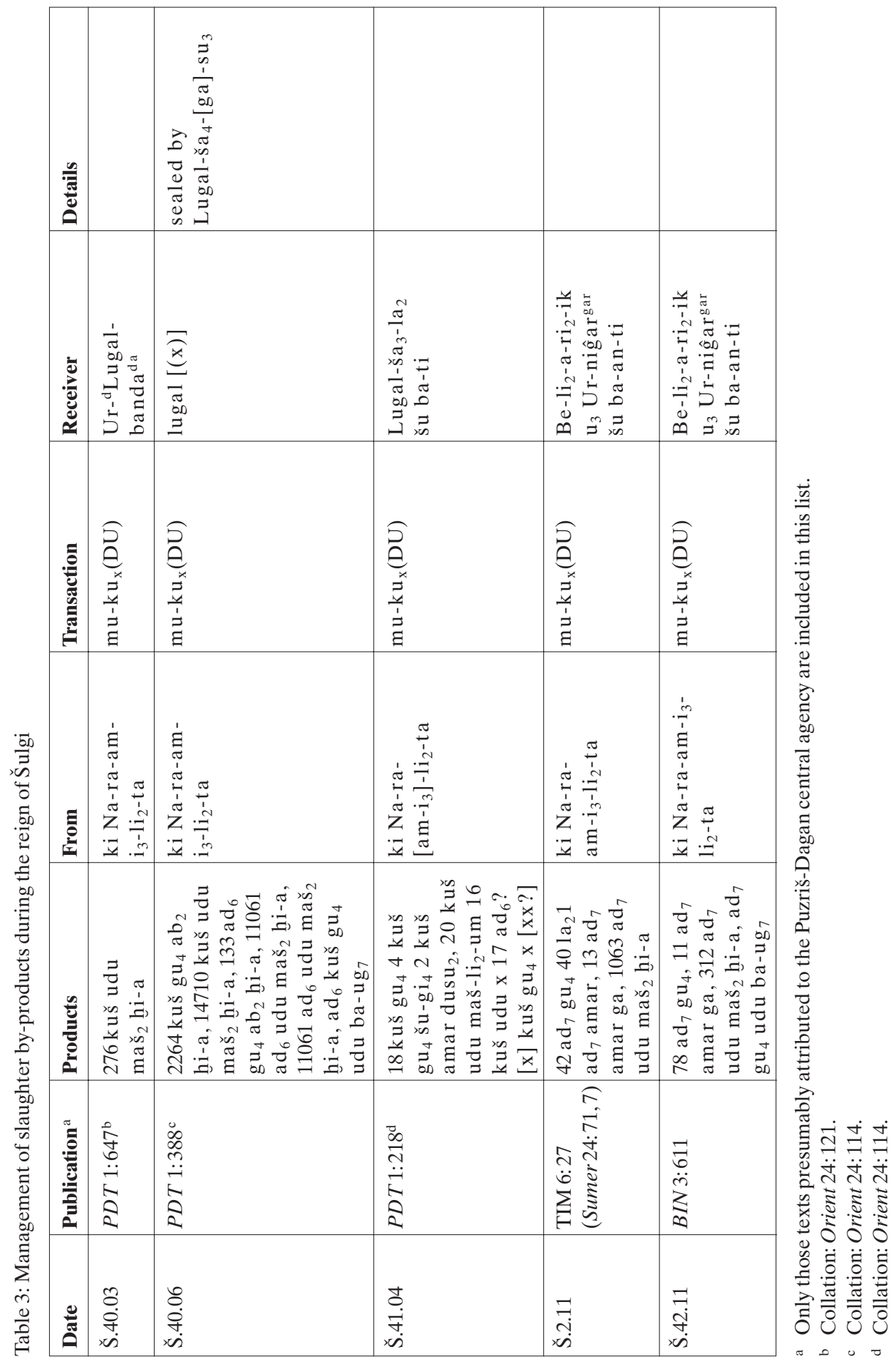




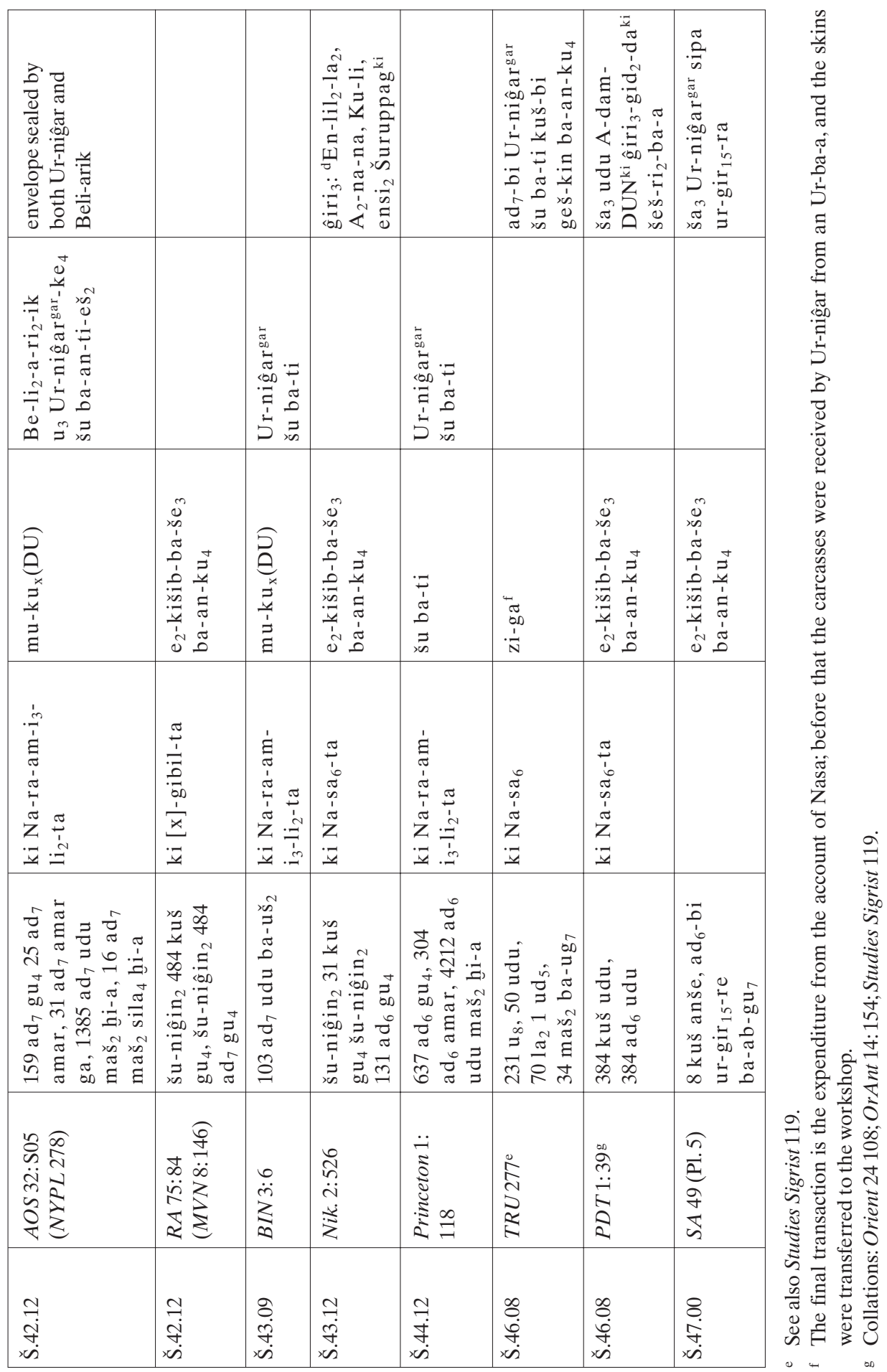




\begin{tabular}{|c|c|c|c|c|}
\hline 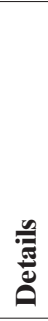 & & 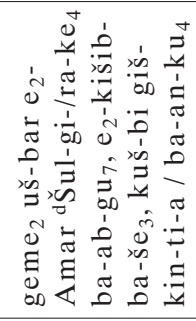 & & \\
\hline 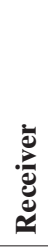 & & & 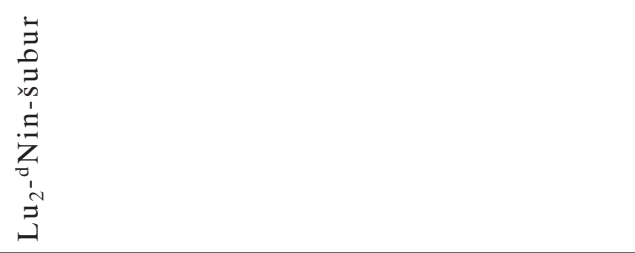 & 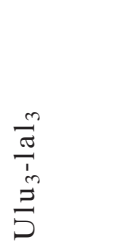 \\
\hline 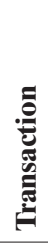 & 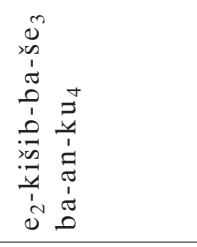 & $\begin{array}{l}\vec{N} \\
\tilde{N} \\
\tilde{0}\end{array}$ & 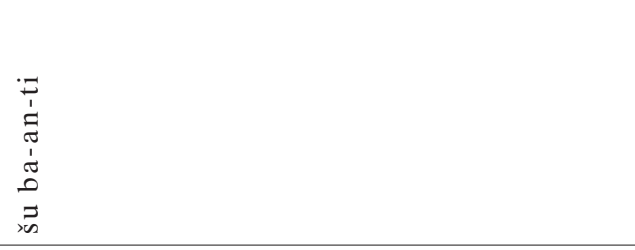 & 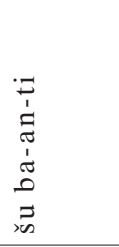 \\
\hline : & 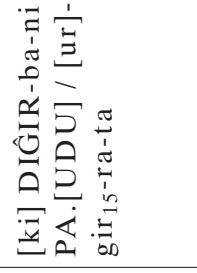 & $\begin{array}{l}\tilde{J} \\
\dot{b} \\
\tilde{d} \\
0 \\
1 \\
\tilde{\sigma} \\
z \\
\bar{z} \\
\underline{E}\end{array}$ & 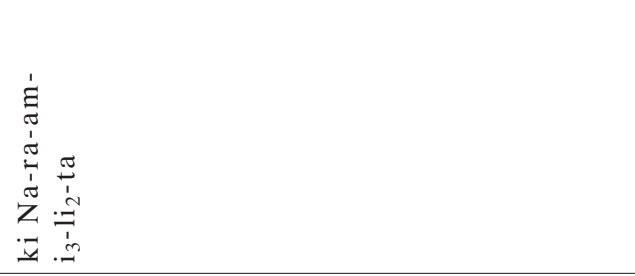 & 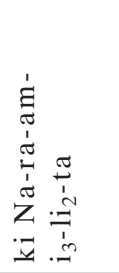 \\
\hline 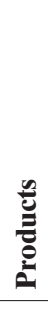 & 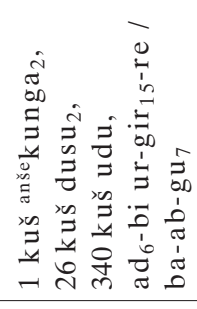 & 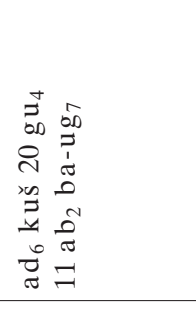 & 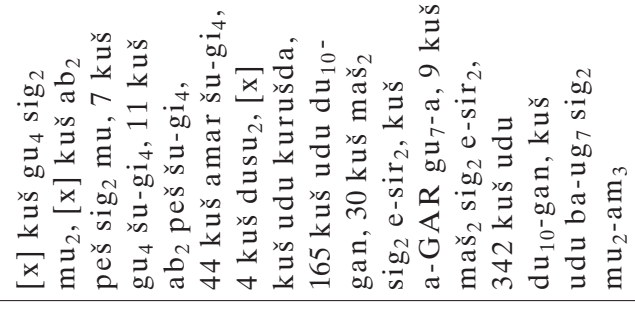 & 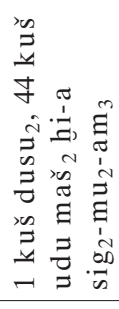 \\
\hline 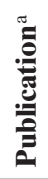 & \begin{tabular}{l}
$\infty$ \\
\multirow{+}{*}{} \\
$\ddot{n}$ \\
$\bar{\Xi}$ \\
$\vdots$
\end{tabular} & 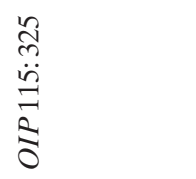 & 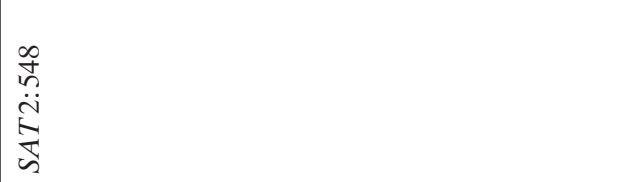 & $\begin{array}{l}\vec{n} \\
\tilde{n} \\
\dot{v} \\
\vec{n} \\
\vec{n}\end{array}$ \\
\hline 气̆ & $\begin{array}{l}8 \\
\dot{+} \\
\dot{y} \\
\dot{s}\end{array}$ & $\begin{array}{l}\vec{b} \\
\dot{+} \\
\dot{s}\end{array}$ & $\begin{array}{c}\vec{\sigma} \\
\dot{+} \\
\dot{v}\end{array}$ & $\begin{array}{l}\tilde{\sigma} \\
\stackrel{+}{+} \\
\dot{n}\end{array}$ \\
\hline
\end{tabular}




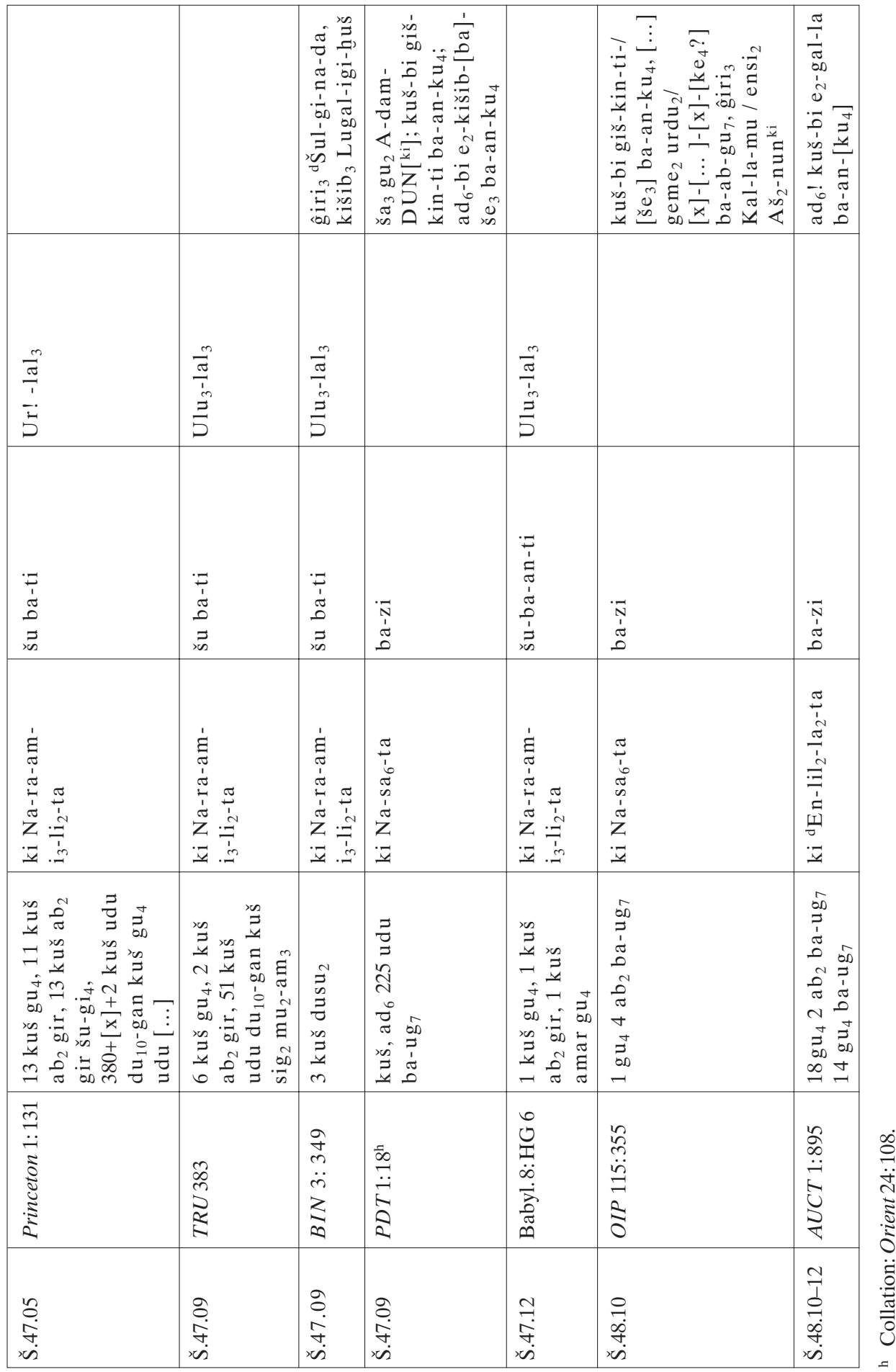




\begin{tabular}{|c|c|c|c|c|c|c|c|c|}
\hline 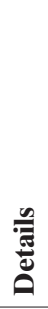 & & 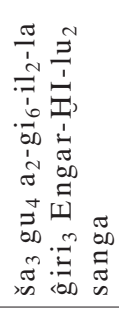 & & & 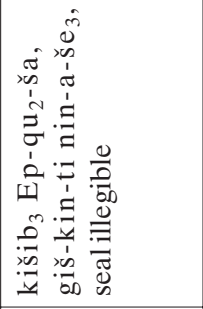 & & & 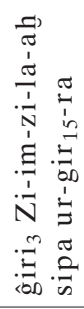 \\
\hline : & 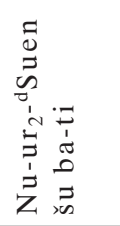 & & 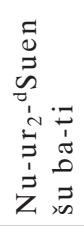 & 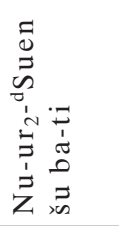 & & 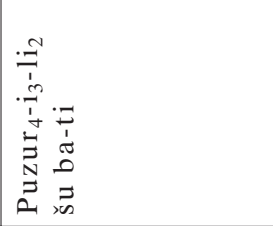 & 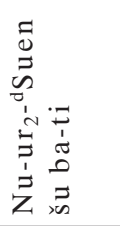 & 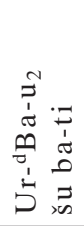 \\
\hline 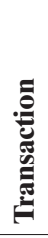 & 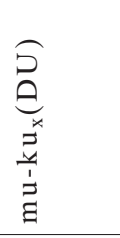 & $\begin{array}{l}\vec{N} \\
1 \\
0 \\
0\end{array}$ & 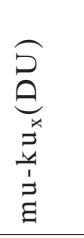 & 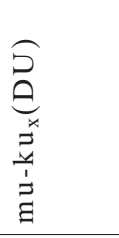 & 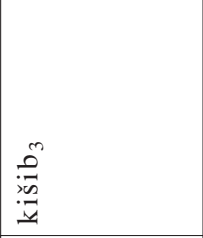 & 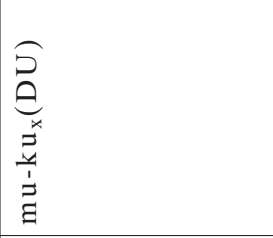 & $\begin{array}{l}\bar{N} \\
\mathbf{N} \\
\tilde{\sigma} \\
\end{array}$ & 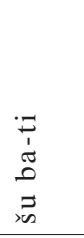 \\
\hline 总 & 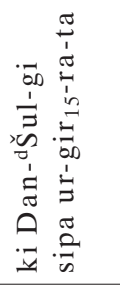 & $\begin{array}{l}\frac{\pi}{1} \\
b \\
0 \\
0 \\
0 \\
0 \\
z \\
-\bar{y}\end{array}$ & 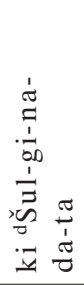 & 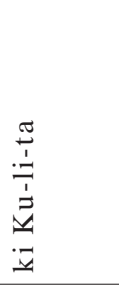 & & 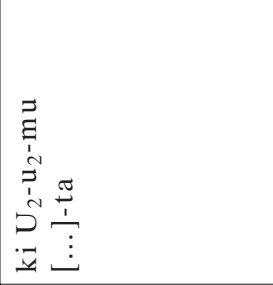 & 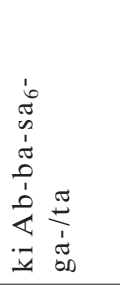 & 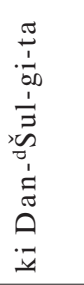 \\
\hline 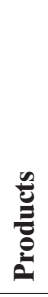 & 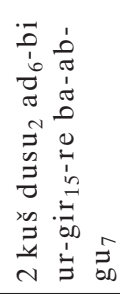 & 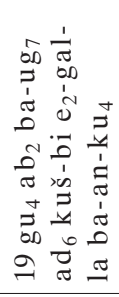 & 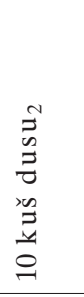 & 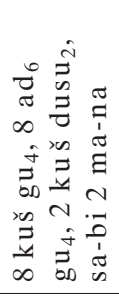 & 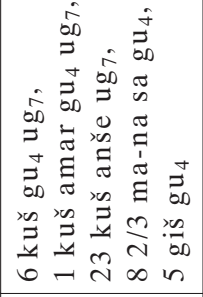 & 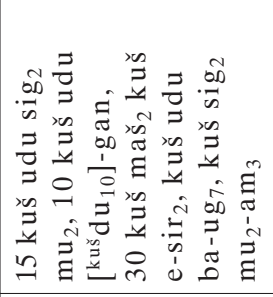 & 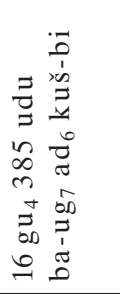 & 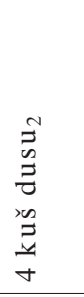 \\
\hline 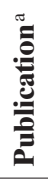 & $\begin{array}{l}\text { ते } \\
\ddot{m} \\
\vdots \\
\vdots\end{array}$ & 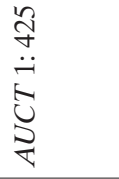 & $\begin{array}{l}\underset{7}{ت} \\
\stackrel{\vec{H}}{0} \\
0\end{array}$ & 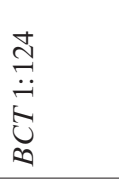 & $\begin{array}{l}\text { N} \\
\text { m } \\
\vdots \\
\vdots \\
\vdots\end{array}$ & 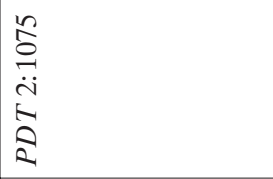 & 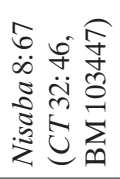 & 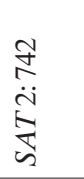 \\
\hline 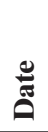 & 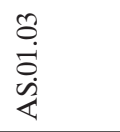 & $\begin{array}{l}8 \\
\dot{8} \\
\dot{0} \\
\dot{4}\end{array}$ & 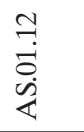 & 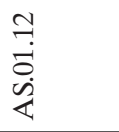 & $\begin{array}{l}8 \\
\text { d. } \\
\dot{1} \\
\dot{4}\end{array}$ & 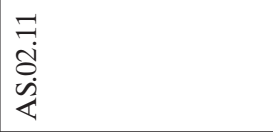 & $\begin{array}{l}8 \\
\infty \\
0 \\
\dot{1}\end{array}$ & $\begin{array}{l}\infty \\
\dot{0} \\
0 \\
\dot{0} \\
\dot{4}\end{array}$ \\
\hline
\end{tabular}




\begin{tabular}{|c|c|c|c|c|c|c|}
\hline & 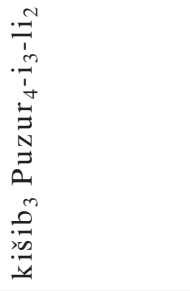 & 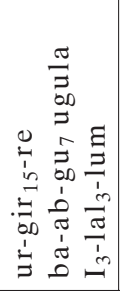 & 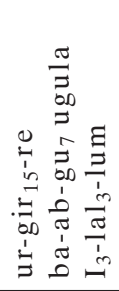 & 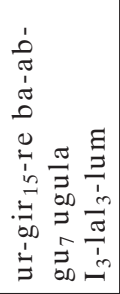 & 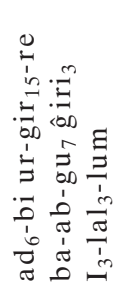 & \\
\hline 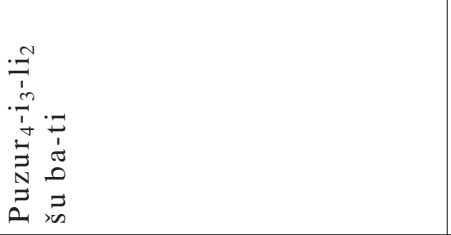 & & 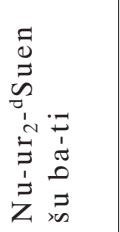 & 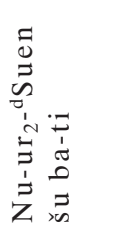 & 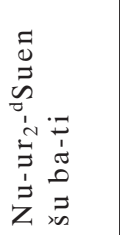 & 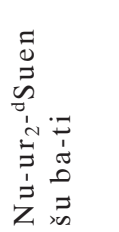 & 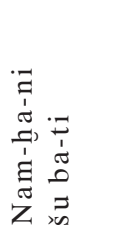 \\
\hline 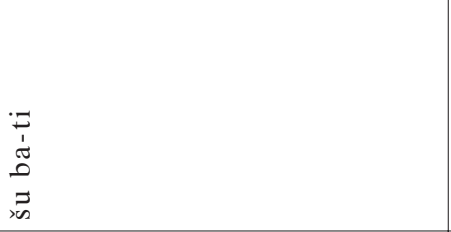 & $\begin{array}{l}\bar{N} \\
\tilde{\sigma} \\
0\end{array}$ & 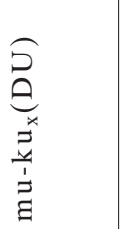 & 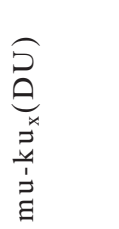 & 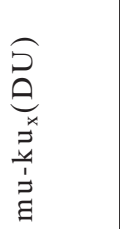 & 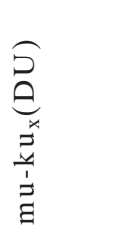 & 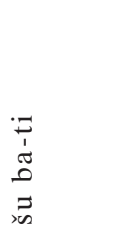 \\
\hline 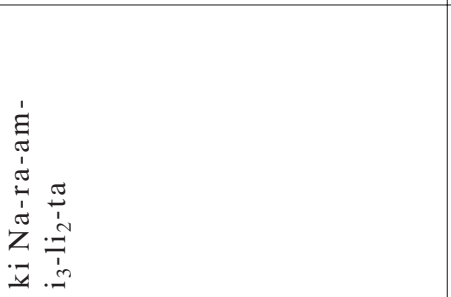 & 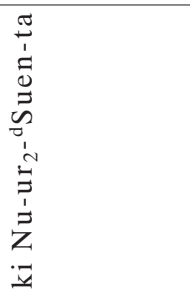 &  & 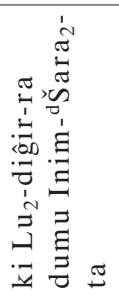 & 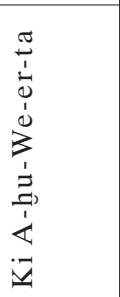 & 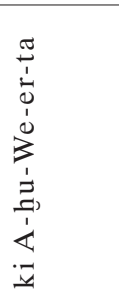 & 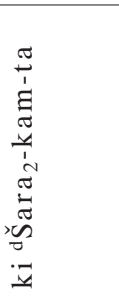 \\
\hline 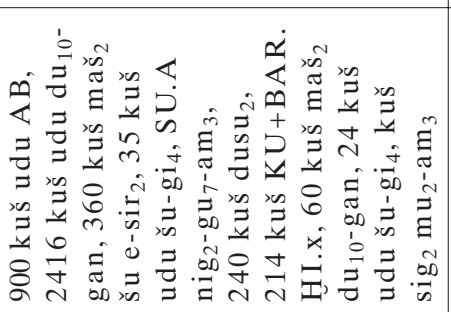 & 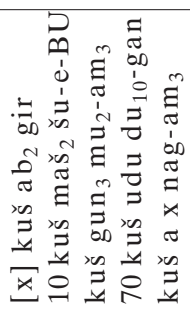 & 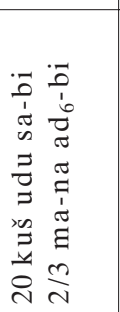 & 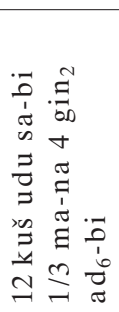 & 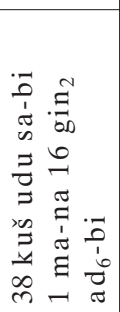 & 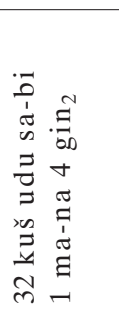 & 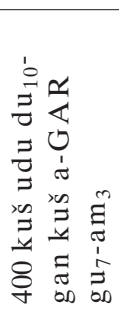 \\
\hline 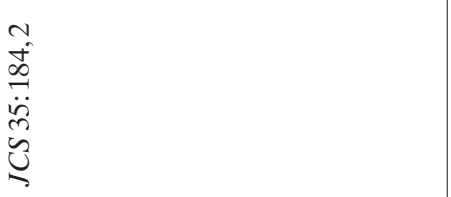 & 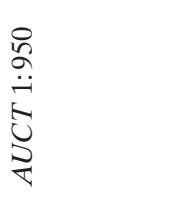 & 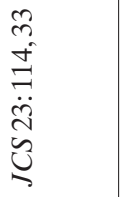 & 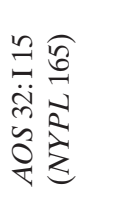 & 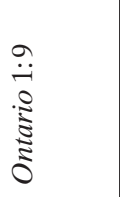 & 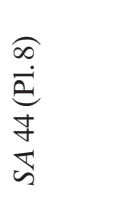 & 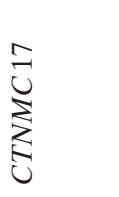 \\
\hline $\begin{array}{l}\dot{0} \\
\dot{8} \\
\dot{0} \\
\dot{4}\end{array}$ & $\begin{array}{l}0 \\
\infty \\
0 \\
\dot{1} \\
<\end{array}$ & $\begin{array}{l}5 \\
\dot{0} \\
0 \\
\dot{\alpha}\end{array}$ & $\begin{array}{l}\infty \\
0 \\
\infty \\
\dot{0} \\
\dot{\alpha}\end{array}$ & 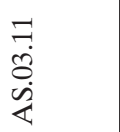 & $\begin{array}{l}\dot{J} \\
\dot{0} \\
\dot{0} \\
\dot{Q}\end{array}$ & $\begin{array}{l}\dot{J} \\
\dot{0} \\
\dot{1} \\
\dot{4}\end{array}$ \\
\hline
\end{tabular}




\begin{tabular}{|c|c|c|c|c|c|c|}
\hline 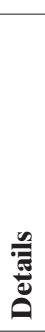 & 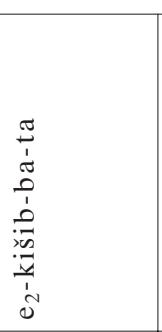 & 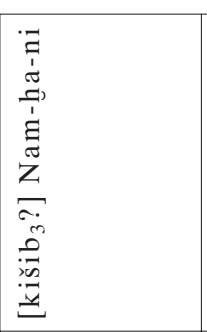 & 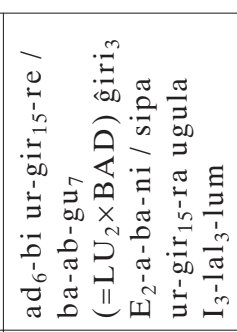 & 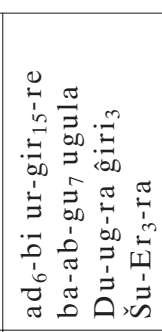 & 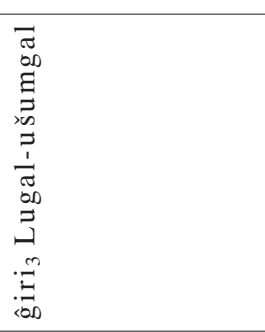 & 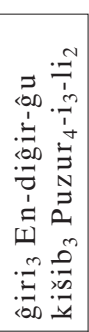 \\
\hline 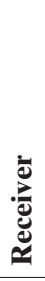 & 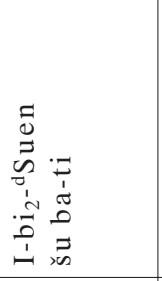 & & 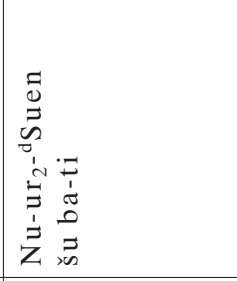 & 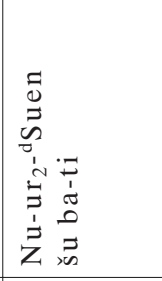 & 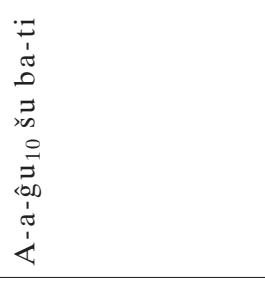 & \\
\hline 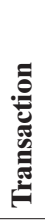 & 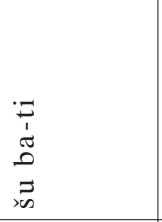 & $\begin{array}{l}\vec{N} \\
\tilde{N} \\
D\end{array}$ & 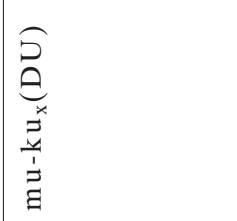 & 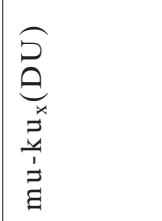 & $\begin{array}{l}\vec{F} \\
0 \\
0 \\
0 \\
\vec{D} \\
\dot{v}\end{array}$ & $\begin{array}{l}\vec{N} \\
\tilde{J} \\
0\end{array}$ \\
\hline 謨 & & 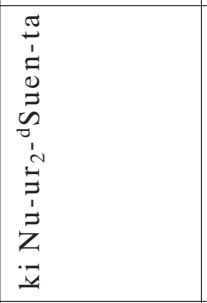 & 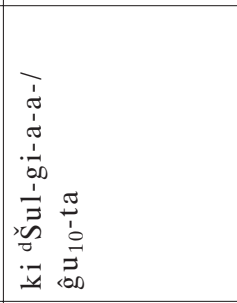 & 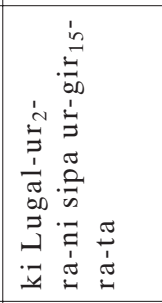 & 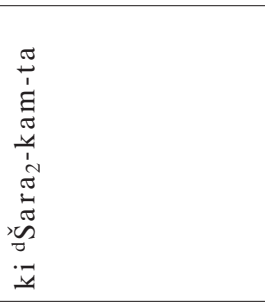 & 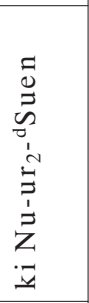 \\
\hline 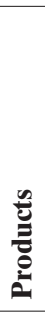 & 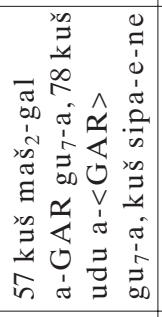 & 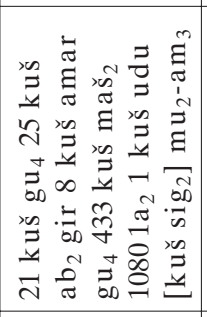 & 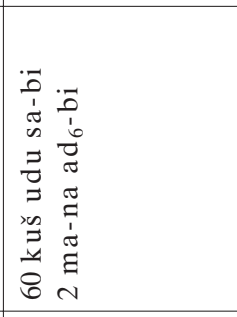 & 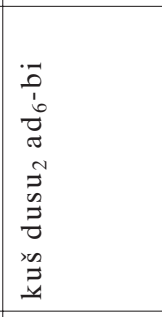 & 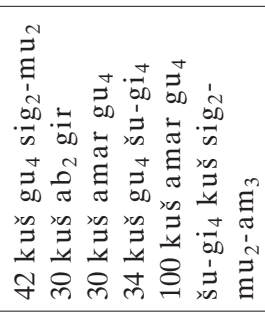 & 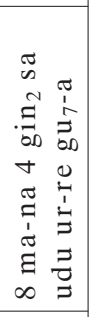 \\
\hline 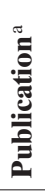 & 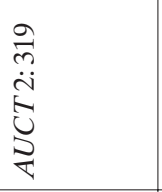 & 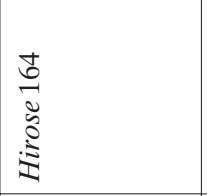 & 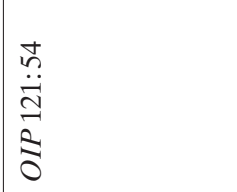 & 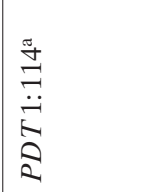 & 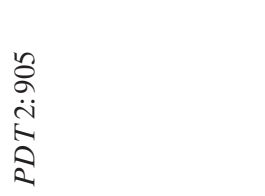 & $\begin{array}{l}\infty \\
\infty \\
\infty \\
\dot{\tilde{V}} \\
\vec{\psi}\end{array}$ \\
\hline ڤે๊๊ & $\begin{array}{l}8 \\
\dot{+} \\
\dot{0} \\
\dot{\hat{s}}\end{array}$ & 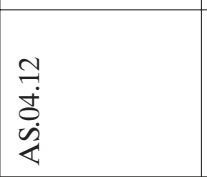 & $\begin{array}{l}0 \\
\dot{1} \\
0 \\
0 \\
\dot{s} \\
\end{array}$ & $\begin{array}{l}= \\
\vec{b} \\
0 \\
\dot{s} \\
\dot{\alpha}\end{array}$ & $\begin{array}{l}\tilde{y} \\
\vec{b} \\
\dot{s} \\
\dot{\alpha}\end{array}$ & $\begin{array}{l}\tilde{1} \\
I \\
0 \\
\dot{0} \\
0 \\
\dot{4} \\
\dot{4}\end{array}$ \\
\hline
\end{tabular}




\begin{tabular}{|c|c|c|c|c|c|}
\hline 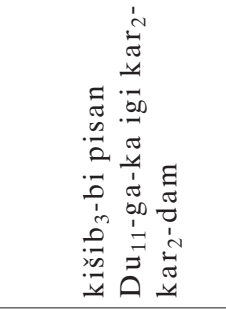 & 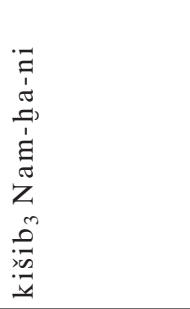 & & & & 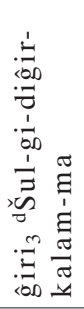 \\
\hline 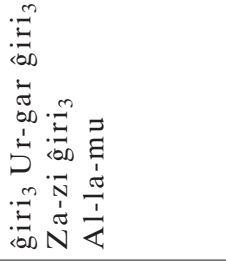 & & 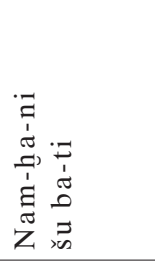 & 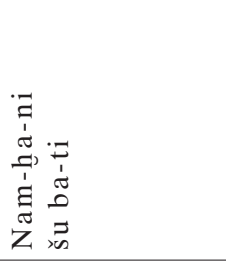 & 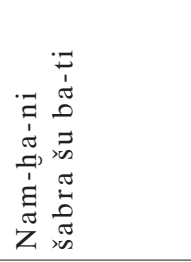 & 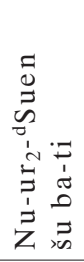 \\
\hline & $\begin{array}{l}\vec{N} \\
\tilde{a} \\
\tilde{D}\end{array}$ & $\begin{array}{l}\overrightarrow{7} \\
1 \\
0 \\
0 \\
\overrightarrow{3} \\
x\end{array}$ & 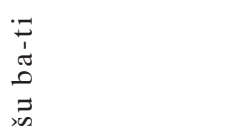 & 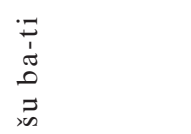 & $\begin{array}{l}\vec{N} \\
\tilde{D} \\
\tilde{D}\end{array}$ \\
\hline & 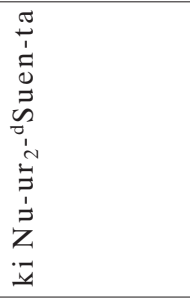 & 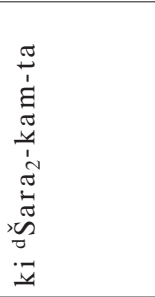 & 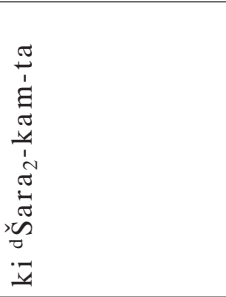 & 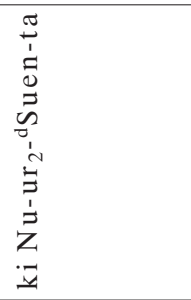 & 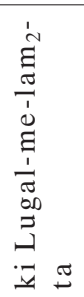 \\
\hline 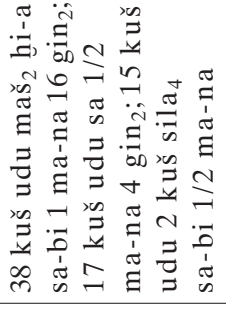 & 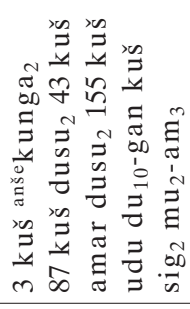 & 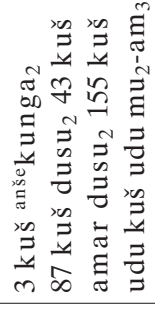 & 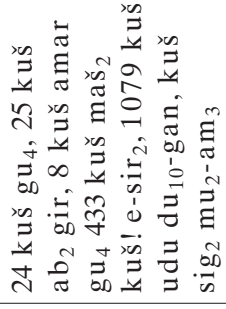 & 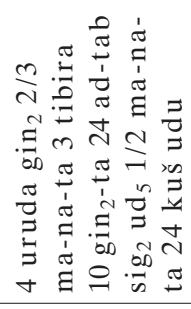 & 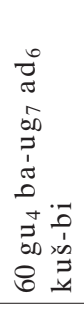 \\
\hline 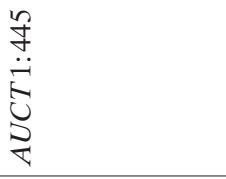 & 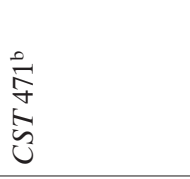 & $\begin{array}{l}m \\
\stackrel{m}{0} \\
\dot{m} \\
\vdots \\
\infty\end{array}$ & 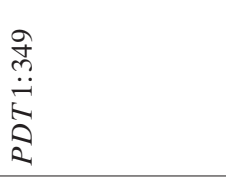 & 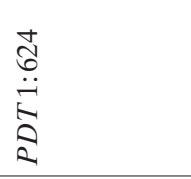 & 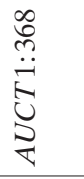 \\
\hline 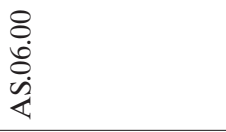 & $\begin{array}{l}0 \\
0 \\
\dot{0} \\
\dot{1}\end{array}$ & $\begin{array}{l}\qquad \\
0 \\
\dot{8} \\
\dot{4} \\
\dot{4}\end{array}$ & 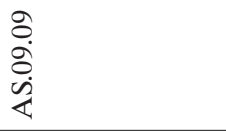 & $\begin{array}{l}\dot{0} \\
\dot{0} \\
\dot{\infty} \\
\dot{n}\end{array}$ & $\begin{array}{l}7 \\
\ddot{8} \\
0 \\
\dot{0}\end{array}$ \\
\hline
\end{tabular}




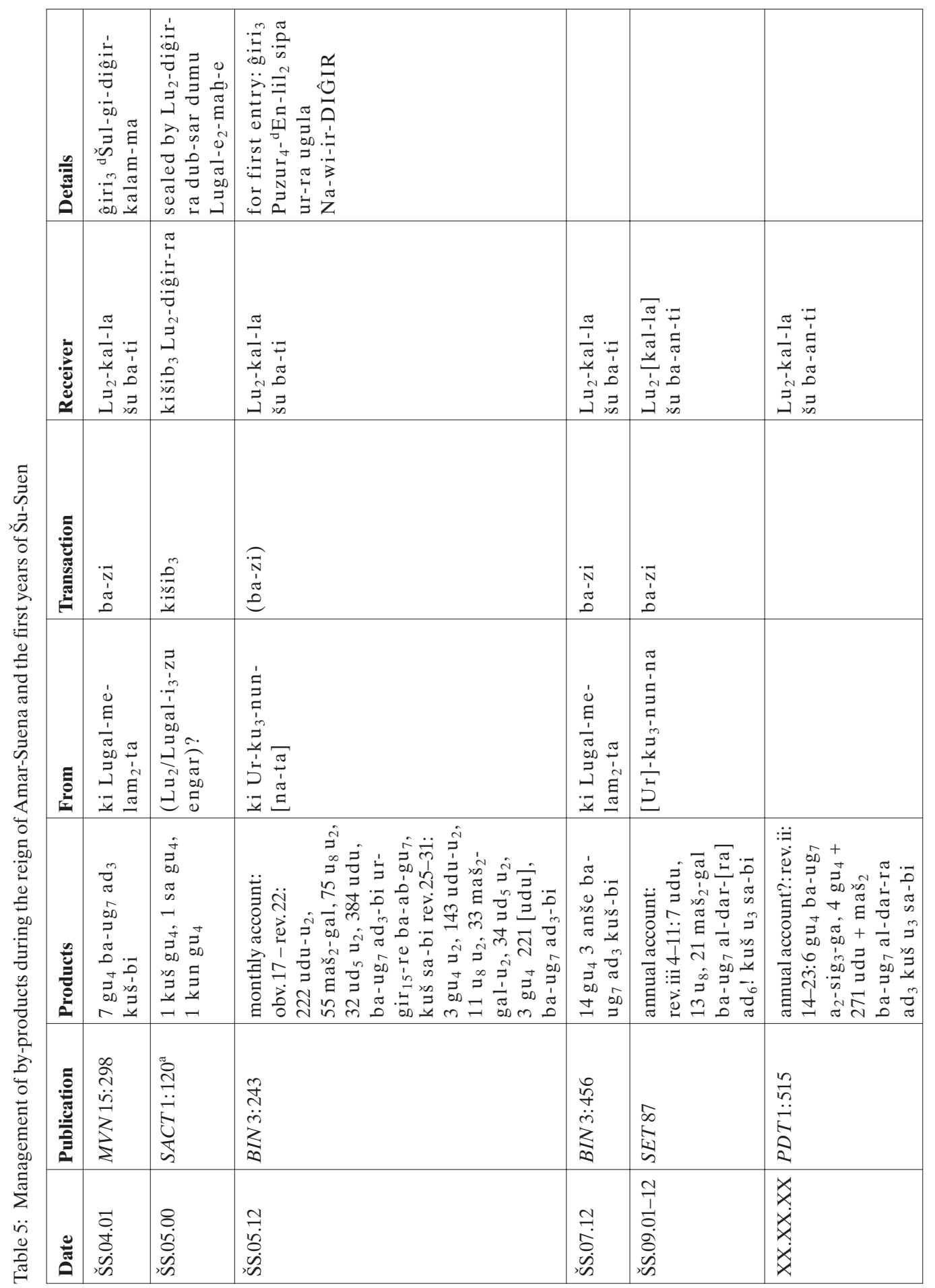




\section{Conclusion}

It has been demonstrated that early in the reign of Amar-Suena, the management of dead animals at Puzriš-Dagan was divided between two different departments. One was concerned with dead animals for the kitchen, including processing the meat. It was headed by Beli-arik, Ur-niĝar and Šulgi-iriĝu. The other was concerned with the disposal of carcasses and processing the by-products, such as skins, tendons and wool. Originally probably headed by Naram-ili, it was subsequently run by Nur-Suen and Lu-kala.

The officials of the first department may have had previous connections with the kitchen, as Ur-niĝar's father was a cook. But those working at the skinning department were not associated with the kitchen or with the workshops at Puzriš-Dagan. They had nothing to do with the disposal of carcasses and were not in any way related to the slaughterhouse. They were in charge of the storeroom that was possibly associated with the palace and where carcasses and hides were stored until a need arose for them to be distributed. If, however, the father of Nur-Suen, a certain Iddin-Erra, is to be identified with the leather worker responsible for collecting wool and who worked within the Šulgi-simti organization during the reign of Šulgi, then there would be reason to suggest that responsibilities and professions ran in the family in this instance as well. 


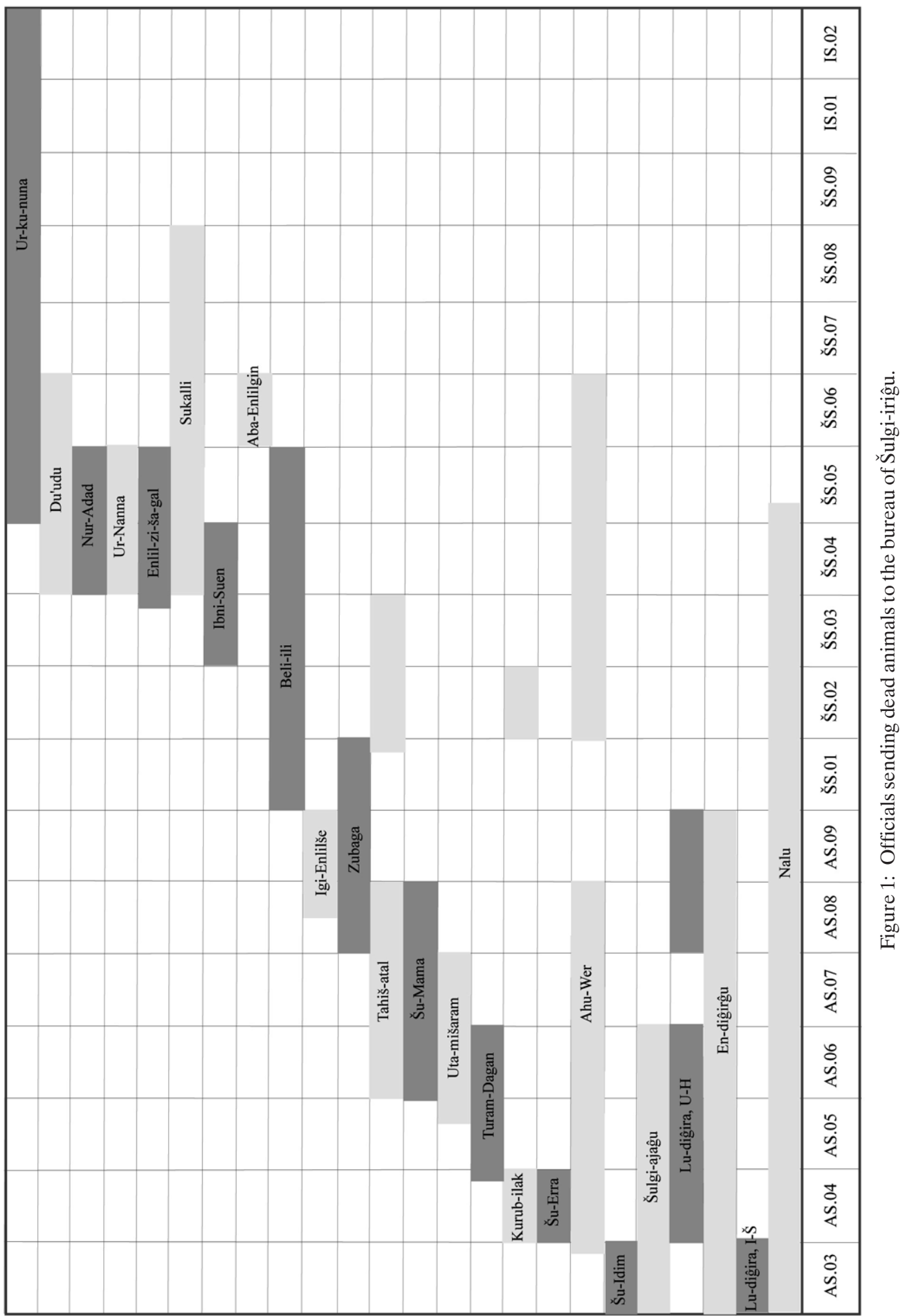




\section{References}

Allred, L. (2006): Cooks and Kitchens: Centralized Food Production in Late Third Millennium Mesopotamia, $\mathrm{PhD}$ thesis, The Johns Hopkins University.

Brunke, H. (2008): The nakabtum - An Administrative Superstructure for the Storage and Distribution of Agricultural Products, Kaskal 5,111-126.

Brunke, H. (2011): Essen in Sumer: Metrologie, Herstellung und Terminologie nach Zeugnis der Ur IIIzeitlichen Wirtschaftsurkunden, Munich.

Cooper, M. (1979): Studies in Neo-Sumerian Administrative Procedures, PhD thesis, University of Minnesota.

Englund, R. (2002): The Ur III Collection of the CMAA, CDLJ 2002/1.

Englund, R. (2003): Worcester Slaughterhouse Account, CDLB 2003/1.

Englund, R. (2004): Banks in Banning. In: H. Waetzoldt (ed.), Von Sumer nach Ebla und zurück: Festschrift für Giovanni Pettinato zum 27. September 1999 gewidmet von Freunden, Kollegen und Schülern (HSAO 9), Heidelberg, 35-44.

Farber, W. (1977): Beschwörungsrituale an Ištar und Dumuzi - atti Ištar ša harmaša Dumuzi, Wiesbaden.

Foxvog, D. A. (1989): A Manual of Sacrificial Procedure. In: H. Behrens, D. Loding and M.T. Roth (eds.), DUMU-E-DUB-BA-A: Studies in Honor of Åke W. Sjöberg (Occasional Publications of the Samuel Noah Kramer Fund 11), Philadelphia, 167-176.

Heimpel, W. (1993): Zu den Bezeichnungen von Schafen und Ziegen in den Drehem- und Ummatexten, BSA 7, 115-160.

Hilgert, M. (2003): Cuneiform Texts from the Ur III Period in the Oriental Institute, Volume 2: Drehem Administrative Documents from the Reign of Amar-Suena (OIP 121), Chicago.

Hilgert, M. (2008): Cuneiform Texts in the Collection of St. Martin Archabbey Beuron, CDLJ 2008/2.

Johnson, C. (2004): Two Ur III Tablets from the Tulare County Library, CDLB 2004/2.

Karahashi, F. (2000): Sumerian Compound Verbs with Body-part Terms, PhD thesis, University of Chicago.

Lafont, B. (2009): La consommation de viande à Sumer. In: C. Michel (ed.), L'alimentation dans l'Orient ancien de la production à la consommation. Cahier des thèmes transversaux ArScAn (vol. IX) 20072008, Nanterre, 421-430.

Layard, A. H. (1849): The Monuments of Nineveh: From Drawings Made on the Spot, Vol.1, London.

Levey, M. (1959): Chemistry and Chemical Technology in Ancient Mesopotamia, New York.

Paoletti, P. (2012): Der König und sein Kreis: das staatliche Schatzarchiv der III. Dynastie von Ur (BPOA 10), Madrid.

Postgate, J. N. (1975): Some Old Babylonian Shepherds and their Flocks, JSS 20,1-21.

Sallaberger,W. (1993): Der kultische Kalender der Ur III-Zeit (UAVA 7), Berlin.

Sallaberger,W. (1994): Keilschrifttexte einer Privatsammlung, AfO 41, 52-63.

Sallaberger, W. (1996): Zur frühen mesopotamischen Briefliteratur. Review of: B. Kienast and K. Volk, Die sumerischen und akkadischen Briefe des III. Jahrtausends aus der Zeit vor der III. Dynastie von Ur, OLZ 91,390-407.

Sallaberger,W. (2004): Schlachtvieh aus Puzriš-Dagan. Zur Bedeutung dieses königlichen Archivs, JEOL $38,45-62$.

Scurlock, J. (2006): The Techniques of the Sacrifice of Animals in Ancient Israel and Ancient Mesopotamia: New Insights Through Comparison, Part 1, Andrews University Seminary Studies 44 (1), 13-49.

Sharlach, T. M. (2004): Provincial Taxation and the Ur III State, Leiden.

Sigrist, M. (1992): Drehem, Bethesda.

Stȩpień, M. (1996): Animal Husbandry in the Ancient Near East: A Prosopographic Study of Third Millennium Umma, Bethesda.

Steinkeller, P. (1995): Sheep and Goat Terminology in Ur III Sources from Drehem, BSA 8, 49-70.

Steinkeller, P. (2008): Joys of Cooking in Ur III Babylonia. In: P. Michalowski (ed.), On the Third Dynasty of Ur: Studies in Honor of Marcel Sigrist (JCS Supplementary Series), Boston, 185-192.

Stol, M. (1983): Leder(industrie). In: RlA 6, 527-543. 
Tsouparopoulou, C. (2012): The "K-9" Corps of the Third Dynasty of Ur. The Dog Handlers at Drehem and the Army, ZA 102,1-16.

Tsouparopoulou, C. (2013): A Reconstruction of the Puzriš-Dagan Central Livestock Agency, CDLJ 2013/2.

Tsouparopoulou, C. (forthcoming): The Ur III Seals Impressed on Cuneiform Documents from Drehem.

Uchitel, A. (1996): Erin-eš-didli (II): Patterns of Conscription and Work Assignment during the Years AS 8 - ŠS 1 , ASJ 18, 217-228.

Veldhuis, N. (2008): Orthography and Politics: adda, "carcass" and kur 9 , "to enter." In: P. Michalowski (ed.), On the Third Dynasty of Ur: Studies in Honor of Marcel Sigrist (JCS Supplementary Series), Boston, 223-230.

Watson, P. J. (1986): A Catalogue of Cuneiform Tablets in Birmingham City Museum, Vol. 1: Neo-Sumerian Texts from Drehem, Warminster.

Wu, Y. (1996): The Ewes without Lambs and Lambs Cooked in É-uz-ga, "The Private House of Kings", in the Drehem Archives, JAC 11, 65-110.

\section{Christina Tsouparopoulou}

Institut für Ur- und Frühgeschichte und Vorderasiatische Archäologie

Universität Heidelberg

Marstallhof 4

D - 69117 Heidelberg

tsouparopoulou@uni-heidelberg.de 